\title{
LncRNAs regulate cancer metastasis via binding to functional proteins
}

\author{
Liting Yang ${ }^{1,2,3}$, Yanyan Tang ${ }^{2}$, Fang Xiong1, Yi He ${ }^{2,4}$, Fang Wei $^{2}$, Shanshan Zhang ${ }^{1}$, \\ Can Guo ${ }^{2}$, Bo Xiang ${ }^{2}$, Ming Zhou ${ }^{2}$, Ni Xie ${ }^{5}$, Xiaoling $\mathrm{Li}^{2}$, Yong $\mathrm{Li}^{2,6}$, Guiyuan $\mathrm{Li}^{1,2,3}$, \\ Wei Xiong ${ }^{1,2,3}$ and Zhaoyang Zeng ${ }^{1,2,3}$

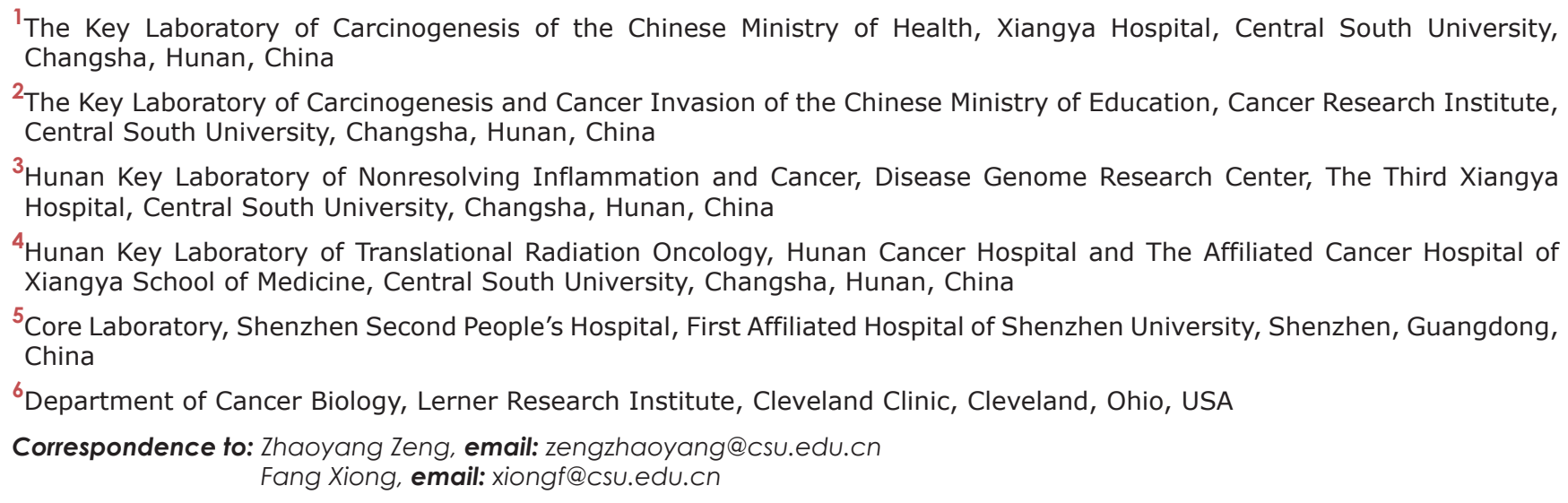
Keywords: IncRNA; functional proteins; metastasis; localization; stabilization

Received: April 05, $2017 \quad$ Accepted: November 13, $2017 \quad$ Published: December 01, 2017

Copyright: Yang et al. This is an open-access article distributed under the terms of the Creative Commons Attribution License 3.0 (CC BY 3.0), which permits unrestricted use, distribution, and reproduction in any medium, provided the original author and source are credited.

\section{ABSTRACT}

Cancer is one of the leading causes of death worldwide, and metastasis is a crucial characteristic of malignancy. Recent studies have shown that IncRNAs play an important role in regulating cancer metastasis through various molecular mechanisms. We briefly summarize four known molecular functions of IncRNAs, including their role as a signal, decoy, guide and scaffold. No matter which pattern IncRNAs follow to carry out their functions, the proteins that IncRNAs bind to are important for them to exhibit their gene-regulating properties. We further illustrate that IncRNAs regulate the localization, stabilization or modification of their binding proteins to realize the binding role of IncRNAs. In this review, we focus on the interactions between IncRNAs and their binding proteins; moreover, we focus on the mechanisms of the collaborative work of IncRNAs and their binding proteins in cancer metastasis, thus evaluating the potential of IncRNAs as prospective novel therapeutic targets in cancer.

\section{BACKGROUND}

Cancer is one of the leading causes of death worldwide, and as one of the hallmarks of cancer, metastasis is a crucial characteristic of malignancy $[1,2]$. Metastasis is a complex multistep process that involves the early invasion and late colonization of cancer cells [3]. Usually, cancer cells undergo morphological alterations and change their cell-cell or cell-matrix interactions to be able to successfully pass through the first steps of the multistep process of metastasis [4-9]. EMT (epithelialmesenchymal transition) is of critical importance in the early events of tumor cell metastatic dissemination by endowing the cells with a more motile, invasive potential [10-15]. On the other hand, MET (mesenchymalepithelial transition) is required for migrating cells to extravasate from the vessels into their target tissues to 
form micrometastases and eventually form a secondary tumor after the cells survive anoikis [16].

LncRNAs (long non-coding RNAs) are a class of transcripts longer than 200 nucleotides with limited protein coding potential [17-22]. In the past, extensive efforts have been made to characterize the involvement of protein-coding genes in cancer metastasis but few for IncRNAs, which have once been thought as the "dark matter" of the genome, because of our limited knowledge about their functions. Up to now, more and more studies have identified that deregulations of IncRNAs are observed in various cancer types, and an abnormal expression of lncRNAs virtually participates in all stages of cancer development, including cancer initiation, progression and metastasis [23-29].

Various modes of molecular interactions were observed for lncRNAs to exhibit their gene-regulating properties in the recent years. Studies indicate that lncRNAs bind to proteins and regulate their functions. In this review, we summarize the role of lncRNAs binding to functional proteins to regulate their localization, stabilization or modification in cancer metastasis.

\section{LncRNAs regulate cancer metastasis through multiple signaling pathways}

Metastasis of cancer cells to a distal site is a particularly critical stage of cancer progression [30-36]. EMT is a critical process during the initiation of cancer metastasis, the changes in this program includes cell morphology, cell-matrix adhesion and migration abilities. E-cadherin, intergrins, and cytokeratins are the most commonly used epithelial markers, while N-cadherin, vimentin and fibronectin are mesenchymal markers [10]. A group of EMT-inducing transcription factors, including Slug, Snail and ZEB1/2 (zinc finger E-box binding homeobox 1/2), are activated during EMT [37]. Growth signals from the tumor stroma, such as TGF- $\beta$ (transforming growth factor) [38-41], EGF (epidermal growth factor), FGF (fibroblast growth factor), PDGF (platelet-derived growth factor), IGF (insulin growth factor) and HGF (hepatocyte growth factor), are responsible for triggering EMT in cancer cells [42-45]. These inducers trigger EMT through a complex signaling network, including several receptor tyrosine kinases (RTKs) and the TGF- $\beta / \mathrm{SMAD}, \mathrm{WNT} / \beta$-catenin, NOTCH, MAPK/ERK, PI3K/Akt and HEDGEHOG signaling pathways [46-60]. The aberrant expression of lncRNAs plays a considerable role in cancer metastasis, and they have emerged as versatile regulators of the EMT related pathways mentioned above (Figure 1).

The TGF- $\beta$ signaling pathway is one of the major pathways responsible for the induction of EMT via a group of transcription factors, including Slug, Snail and Twist [61, 62]. LncRNA-HIT (LncRNA-HOXA transcript induced by TGF- $\beta$ ) is one of the most upregulated
IncRNAs induced by TGF- $\beta$ [63]. The upregulation of LncRNA-HIT promotes the migration and invasion of NSCLC by directly associating with ZEB1 [64]. The knock down of $\ln C R N A-A T B$ impedes the induction of EMT by TGF- $\beta$ in HCC and colon cancer $[65,66]$. ZEB2$A S 1$, MALAT1 and linc01133 also play a critical role in the TGF- $\beta$ signaling pathway [67-69].

The canonical WNT/ $\beta$-catenin pathway also plays an important role in the regulation of cancer metastasis $[70,71]$. $\beta$-catenin is a core component of the cadherin protein complex, whose localization and stabilization are essential for the activation of WNT/ $\beta$-catenin signaling $[72,73]$. Several lncRNAs are involved in $\mathrm{WNT} / \beta$ catenin pathway regulation. For example, HOTAIR (HOX transcript antisense RNA) epigenetically silences the Wnt inhibitor WIF1, while the loss of WIF1 enhances the migratory ability of glioblastoma cells through WNT5A activation mediated via MALAT1 [74, 75]. The IncRNA H19, TINCR, and IncTCF7 also play critical roles in the regulation of cancer metastasis via the $\mathrm{WNT} / \beta$-catenin pathway [76-78].

MAPK/ERK signaling is an element in lncRNAs that mediates the regulation of metastasis. MALAT1 promotes the metastasis of gallbladder carcinoma through the activation of the MAPK/ERK pathway [79]. UCA1 (lncRNA urothelial carcinoma-associated 1) plays a pivotal role in the tumorigenesis of HCC by acting as a ceRNA for miR-216b, leading to the suppression of FGFR1 (fibroblast growth factor receptor 1) expression and the activation of the MAPK/ERK signaling pathway [80].

In addition to their roles in the pathways mentioned above, several lncRNAs also utilize the PI3K/Akt signaling pathway in metastasis regulation. Linc00152 directly binds with EGFR, which activates PI3K/Akt signaling in gastric cancer [81]. The downregulation of MALAT1 induces EMT via the PI3K/Akt pathway in breast cancer [82], and in contrast, the upregulation of MALAT1 promotes the metastasis of osteosarcoma cells by activating the PI3K/Akt pathway [83].

LncRNAs regulate metastasis using additional pathways, such as the Notch and Hedgehog signaling pathways [84-88]. There are so many patterns for IncRNAs to regulate cancer metastasis, and thus, a particular focus on the molecular mechanisms of lncRNAs in metastasis is needed.

\section{Roles of IncRNAs in regulating protein functions}

LncRNAs use various modes of molecular interactions to exhibit their gene-regulating properties from transcriptional to posttranscriptional regulation. The functional domains of IncRNAs include RNA-binding domains, DNA-binding domains and protein-binding domains [89]. Thanks to structural plasticity, IncRNAs can act as signals, decoys, guides and scaffolds [90]. 
LncRNAs show a type-specific expression and respond to various stimuli, suggesting that lncRNAs can serve as molecular signals [90]. As signals, lncRNAs mark space, time, and expression for gene regulation. For instance, lincRNA-p21 is a transcriptional target of p53 and plays a role in triggering apoptosis [91]. Other lncRNAs, such as HOTAIR [92] and Xist (X-inactivespecific-transcript) [93], also function as signals, and they usually serve as markers of biological events and are capable of delivering further signals.

LncRNAs act as molecular decoys, because they possess an RNA motif, which binds and titrates away proteins or RNA targets. Some lncRNAs, acting as a "sponge" of miRNAs, also belong to this archetype. In this type, lncRNAs function as CeRNAs (competing endogenous RNA), and vie with mRNAs for miRNAs with shared MREs (miRNAs responses elements) and act as a modulator of miRNAs by influencing the available level of miRNAs $[94,95]$. Sponge LncRNAs, such as $H 19$ [64, 96-99], HOTAIR [100-102], MALAT1 [69, 103107], UCA1 [108-111], XIST [112, 113], HULC [114], lincRNA-ROR [115], lnc-FTX [116], NEAT1 [117, 118], SNHG1 [119], TUG1 [120], and TUSC7 [121], are typical examples.

The third molecular role of lncRNAs is a guide. By acting as a guide, lncRNAs bind to proteins and then direct the localization of the resultant complex to specific targets [90]. Guide lncRNAs directly interact with DNA and RNA by base pairing, and highly structured lncRNAs also provide docking sites for binding proteins [122]. For example, lncRNA HOTTIP directly binds the adaptor protein WDR5 and targets WDR5/MLL complexes to the $H O X A$, increasing the $\mathrm{H} 3$ lysine 4 trimethylation of the HOXA cluster to cause gene transcription [90]. There are many other lncRNAs that function as guides, such as HOTAIR [92] and SChLAP1 [123].

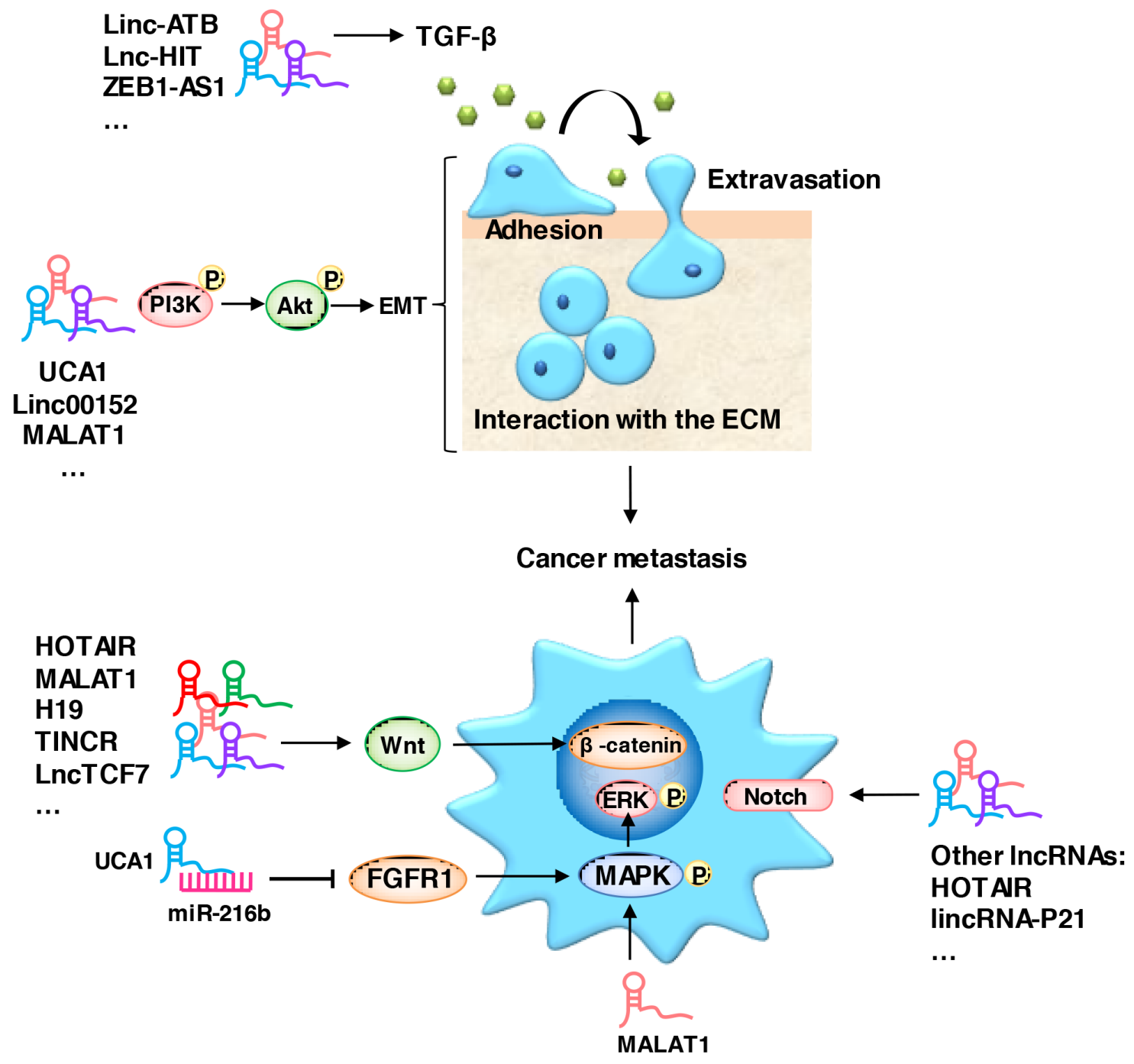

Figure 1: LncRNAs act as regulators of metastasis-related signaling pathways. An aberrant expression of lncRNAs promotes cancer metastasis via the TGF- $\beta /$ SMAD, WNT/ $\beta$-catenin, NOTCH, MAPK/ERK, PI3K/Akt and HEDGEHOG signaling pathways. 
The fourth function of lncRNAs is a scaffold. LncRNAs serve as central platforms on which different effector molecules are assembled. The function of LncRNAs as scaffolds is perhaps the most functionally intricate and complex class, in which the lncRNAs possess different domains that bind distinct effector molecules [90]. One example is Kcnq1ot1, which binds both PRC2 and G9a to promote H3K27me3 and H3K9me3 [124]. Other lncRNAs such as ANRIL (CDKN2B antisense RNA 1) $[125,126]$, HOTAIR [127], and GClncl (gastric cancerassociated lncRNA 1) [128] also function as scaffolds to regulate gene expression.

As a whole, the archetypes mentioned above are not mutually exclusive. LncRNAs play regulatory functions through either RNA-protein or RNA-DNA recognition rules. No matter which archetype lncRNAs carry out their functions, the proteins they bind to are important for them to exhibit their metastasis-regulating performances. In general, lncRNAs complex with various proteins to regulate their localization, stabilization or modification.

\section{LncRNAs regulate the localization of binding proteins}

Chromatin-modifying proteins are a major group of lncRNA binding proteins, and lncRNAs bind to and guide them to specific sites in the genome to regulate metastasisrelated genes expression in space and time. A prominent example of a histone-modifying complex interacting with lncRNAs is PRC2, a histone methyltransferase that catalyzes the mono-, di- and trimethylation of $\mathrm{H} 3 \mathrm{~K} 27$, which is required for epigenetic silencing during development and cancer. The core PRC2 complex is composed of four proteins, including EZH1/2, SUZ12, EED and RbAP46/48 [129]. Until now, the question of how the histone-modifying complex identifies its binding sites on the chromatin remains open, and studies on lncRNAs may give us new and exciting answers. HOTAIR, a lncRNA first identified by Rinn et al., interacts with PRC2 and is required for PRC2 occupancy on the HOXD locus [92]. Later, researchers found that HOTAIR is upregulated in different kinds of cancers and promotes cancer metastasis through by regulating the localization of PRC2 [130-133]. Mechanistically, HOTAIR recruits the PRC2 complex to specific target genes genome-wide, leading to $\mathrm{H} 3 \mathrm{~K} 27$ trimethylation and epigenetic silencing of metastasis suppressor genes. LncRNAs also functions as molecular scaffold to link PRC2 and other modification proteins [127, 134-136]. For example, HOTAIR functions as a molecular scaffold to link and target the histone modification complexes PRC2 and LSD1 and then reprograms chromatin states by coupling histone H3K 27 methylation and $\mathrm{H} 3 \mathrm{~K} 4$ demethylation for epigenetic gene silencing to promote cancer metastasis (Figure 2A).

Another example is $S C h L A P 1$, which is a lncRNA upregulated in prostate cancer. SChLAPl promotes prostate cancer invasiveness and metastasis by binding to SWI/SNF and titrating it away from the chromatin [123]. The mammalian SWI/SNF complex mediates ATP-dependent chromatin remodeling processes, and a substantial of evidence indicates that several components of the SWI/SNF complexes function as tumor suppressors [137]. In detail, SChLAP1 interacts with SNF5 (also known as SMARCB1, an essential subunit that facilitates SWI/SNF binding to histone proteins) and functions as a molecular decoy that sequesters the SWI/SNF chromatinmodifying complex away from the selective gene loci to inhibit metastasis suppressor gene expression (Figure 2B).

MLL1 is a member of the evolutionarily conserved SET1 family of histone H3 lysine4 (H3K4) methyltransferases, which are required for the regulation of distinct groups of developmentally regulated genes $[138,139]$. WDR5 is a core subunit of MLL1 and acts as an "effector" of H3K4 methylation in gene transactivation [128]. Sun et al. identified a novel lncRNA, GClnc1, which promotes gastric cancer metastasis [106]. In detail, GClnc1 upregulates the transcription of SOD2 (dismutase 2 mitochondrial) by acting as a scaffold to recruit the WDR5 and KAT2A (histone acetyltransferase) complex to the SOD2 promoter and increasing the $\mathrm{H} 3 \mathrm{~K} 4$ trimethylation and $\mathrm{H} 3 \mathrm{~K} 9$ acetylation levels in the SOD2 promoter region (Figure 2C). Upregulated SOD2 expression consequently promotes metastasis.

p300 is a HAT (histone acetyltransferase) member that acetylates histone proteins by transferring an acetyl group from acetyl-CoA to specific lysine residues [140]. The acetylation of histones by HATs results in a dispersed structure of chromatin, which becomes accessible to transcriptional factors [141]. ZEB1-AS1 promotes cell migration in osteosarcoma by directly binding and recruiting p300 to the $Z E B 1$ promoter, which induces an open chromatin structure and activates $Z E B 1$ transcription [142] (Figure 2D).

In addition to chromatin-modifying proteins, transcription factors also interact with lncRNAs. A study identified that IncRNAs guide transcription factors to specific sites in the genome. For example, SLNCR (SRA-like non-coding RNA) contains a conserved 300 nucleotide region with a significant similarity to steroid receptor RNA activator 1 (SRA1). Schmidt et al. [143] reported that Brn3a (a member of the Brn 3 family of POU-domain transcription factors) and AR (a steroid-hormone activated transcription factor) bind to SLNCR1's conserved sequence and an adjacent sequence, respectively. The SLNCR1/AR/Brn3a ternary complex has a high affinity for the AR and Brn3a binding sites located upstream of the $M M P 9$ transcription start site, and the cooperative binding of AR and Brn3a to its promoter increases $M M P 9$ expression and activity and, thus, increases the invasion of melanoma cells (Figure 2E). Another prominent example is BCAR4 (breast cancer anti-estrogen resistance 4 ), which contributes to 
tumor metastasis by binding to SNIP1 (SMAD nuclear interacting protein 1) and PNUTS (a phosphatase). In response to cytokine stimulation, $B C A R 4$ lifts the inhibitory effect of SNIP1 on p300, leading to the acetylation of histones, such as H3K18ac. Acetylated histones are necessary for the BCAR4-mediated recruitment of PNUTS, which in turn leads to the active polymerase II at GLI2 controlled genes [144] (Figure 2F).
A

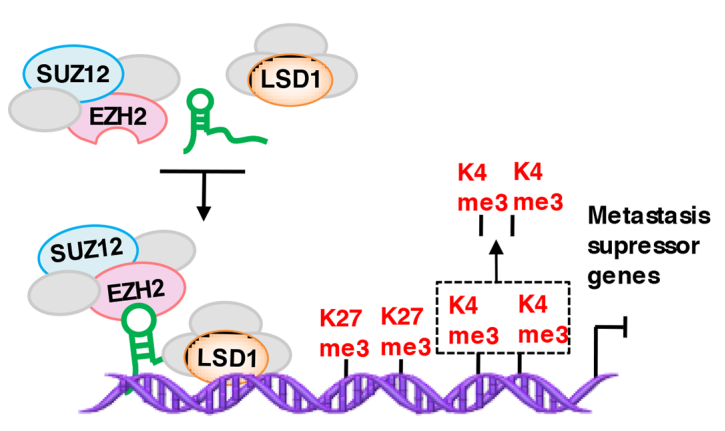

C

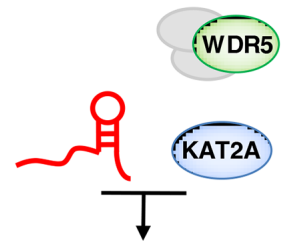

B

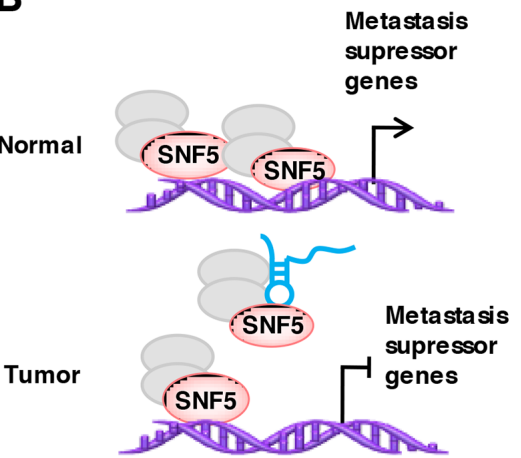

D
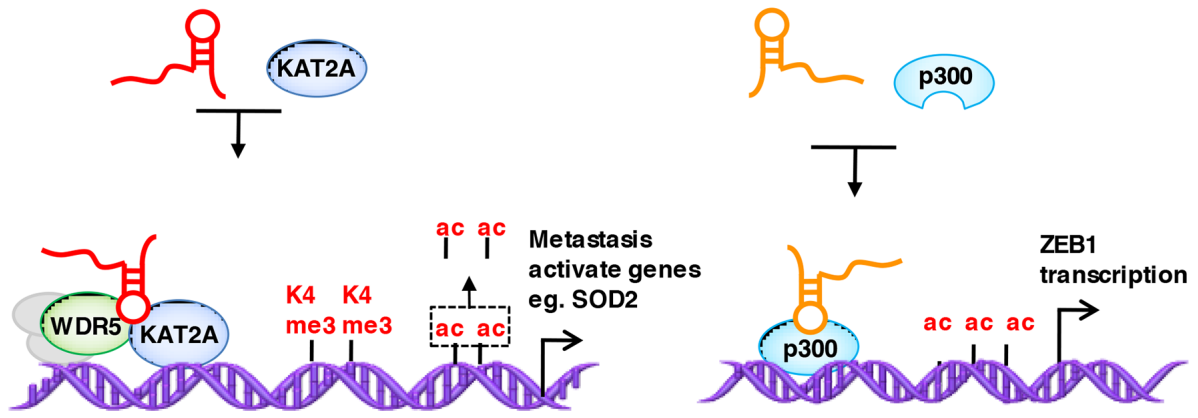

E

$\mathbf{F}$
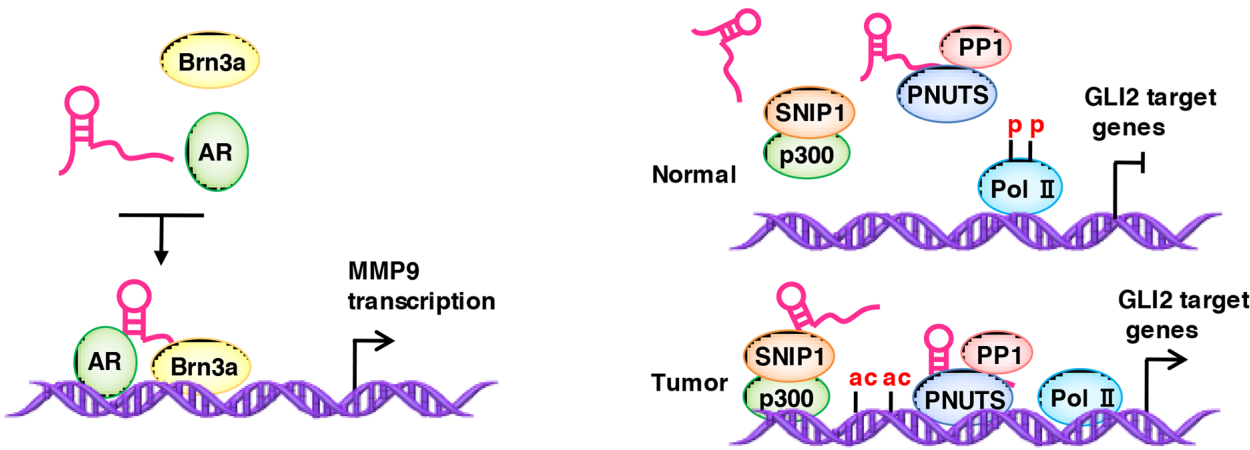

Figure 2: LncRNAs regulate the localization of the chromatin modification complex. (A) HOTAIR functions as a molecular scaffold to link and target PRC2 and LSD1, which then reprograms chromatin states by coupling histone H3K27 methylation and H3K4 demethylation for epigenetic gene silencing to promote cancer metastasis. (B) SChLAP1 interacts with SNF5 and functions as a molecular decoy that sequesters the SWI/SNF chromatin-modifying complex away from selective gene loci to regulate gene expression. (C) GClnc1 upregulates the transcription of SOD2 by acting as a scaffold to recruit the WDR5 and KAT2A complex to the SOD2 promoter, increasing $\mathrm{H} 3 \mathrm{~K} 4$ trimethylation and H3K9 acetylation levels in the SOD2 promoter region. (D) ZEB1-AS1 directly binds and recruits p300 to the ZEB1 promoter, which induces an open chromatin structure and activates ZEB1 transcription. (E) SLNCR1 binds to AR and Brn3a. The SLNCR1/AR/Brn3a ternary complex, located upstream of the MMP9 transcription start site, increases MMP9 expression. (F) BCAR4 binds to SNIP1 and PNUTS. In response to cytokine stimulation, BCAR4 lifts the inhibitory effect of SNIP1 on p300, leading to the acetylation of histones, which in turn leads to the activation of polymerase II at GLI2 controlled genes. 
The lncRNAs mentioned above guide the binding proteins to chromatin or titrate the binding proteins away from the chromatin to regulate gene expression directly. LncRNAs can also decoy the protein from it RNA targets or interact proteins. For example, LINC01133, which is downregulated by TGF- $\beta$, inhibits EMT and metastasis in colorectal cancer [69]. Mechanistically, LINC01133 acts as key downstream molecule in the TGF- $\beta$ pathway and inhibits the EMT in colorectal cancer by directly binding to SRSF6 (serine and arginine rich splicing factor 6) as a target mimic. The authors speculate that LINC01133 may act as a decoy element, titrating SRSF6 away from it RNA targets by directly binding to its critical domain to block the induction of EMT. However, how SRSF6 regulates colorectal cancer cell EMT is still unknown. Another study found that MALAT1 promotes colorectal cancer cell metastasis by competitively binding to PSF and releasing SFPQ from the SFPQ/PTBP2 (polypyrimidine tract binding protein 2) complex, which then increases the SFPQ-detached proto-oncogene PTBP2 [145].

\section{LncRNAs regulate the stabilization of binding proteins}

Like all macromolecular components of an organism, the proteome is in a dynamic state of synthesis and degradation. The proteolytic equilibrium of the proteins is disturbed and the microenvironment is changed in pathophysiological conditions [146]. Studies find that lncRNAs play an important role in regulating the stabilization of binding proteins.

TINCR (Terminal differentiation-induced lncRNA) was first reported by Markus et al. [147], and they declared that the 3.7-kilobase lncRNA controls human epidermal differentiation by a post-transcriptional mechanism. Then, Zhang et al. [77] found that the loss of TINCR expression promotes colorectal cancer metastasis by specifically binds to EpCAM, preventing its proteolysis. EpCAM is expressed at the basolateral membrane of most normal epithelial cells but is over-expressed in many epithelial cancers. The loss of TINCR promotes the hydrolysis of EpCAM and then releases EpICD (EpCAM c-term, intracellular domain), which is one of the components of the Wnt pathway, and colocalizes with FHL2 and $\beta$-catenin to form a nuclear protein complex, leading to gene transcription and, subsequently, activating the Wnt/ $\beta$ catenin pathway [77, 148] (Figure 3A).

LncRNA-LET inhibits the metastasis of HCC and colorectal cancer cells, which are suppressed by HDAC3 (histone deacetylase 3 ) in hypoxia conditions

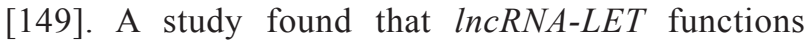
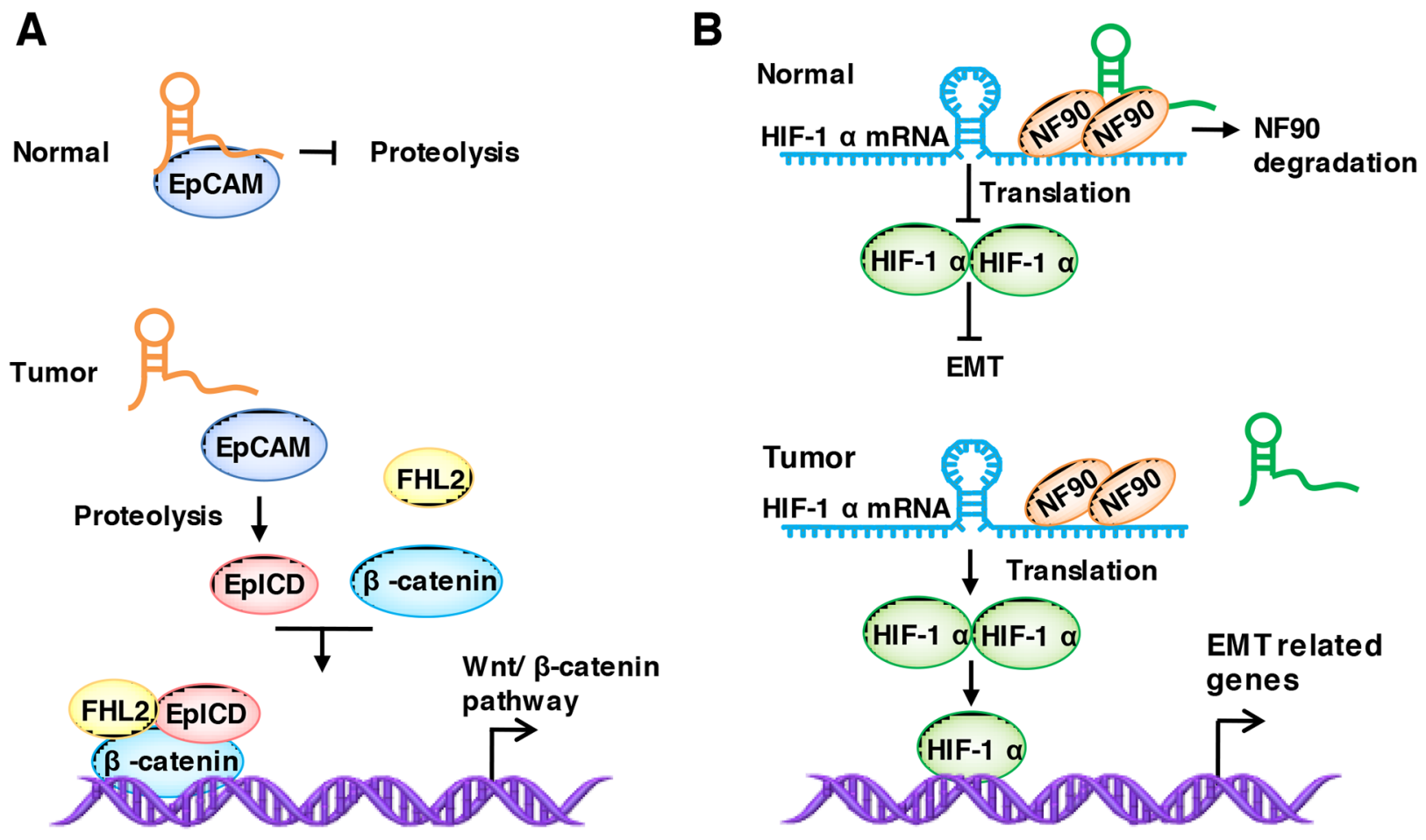

Figure 3: LncRNAs regulate the stabilization of binding proteins. (A) TINCR binds to EpCAM and prevent its proteolysis. The loss of TINCR promotes the hydrolysis of EpCAM and releases EpICD. EpICD colocalizes with FHL2 and $\beta$-catenin to form a nuclear protein complex, leading to gene transcription. (B) LncRNA-LET binds to NF90 and enhances its degradation, thereby affecting HIF-1 $\alpha$ mRNA accumulation and stability under hypoxic conditions, and the inactivation of HIF-1 $\alpha$ results in the decreased expression of EMTrelated proteins, thus leading to the inhibition of EMT, motility and invasiveness. 
through its association with NF90, which is a doublestrand RNA-binding protein that has been implicated in the stabilization, transport, and translational control of many target mRNAs, including $H I F-1 \alpha$ (hypoxia-inducible factor 1 alpha subunit) [150]. Mechanistically, $\operatorname{lncRNA-LET}$ binds to NF90 and enhances its degradation, which thereby affects $H I F$ $1 \alpha$ mRNA accumulation and stability under hypoxic conditions, and the inactivation of $H I F-1 \alpha$ results in the decreased expression of EMT-related proteins, leading to an inhibition of EMT, motility and invasiveness [121, 149] (Figure 3B).

LncRNA-HIT promotes metastasis in NSCLC (nonsmall cell lung cancer) via specially binding to ZEB1 [64]. ZEB factors contain multiple domains that interact with other transcription factors, which is essential for the regulation of EMT [151, 152]. Mechanistically, the association between LncRNA-HIT and ZEB1 protects ZEB1 from proteasome degradation. Upregulated LncRNA-HIT promotes migration and invasion via increasing the occupancy of ZEB on the promoter region of $C D H 1$ [64]. LncRNA $A O C 4 P$ (amine oxidase, copper containing 4, pseudogene) is another lncRNA that regulates the EMT marker protein directly. LncRNA AOC4P suppress EMT in HCC by binding to vimentin, the major component of the cytoskeleton, and enhancing its degradation [153].

\section{LncRNAs regulate the post-translational modification of binding proteins}

$\mathrm{NF}-\mathrm{kB}$ is a family of transcription factors, and aberrant NF-kB activation promotes cancer invasion and metastasis [154-156]. Liu et al. [157] identified the lncRNA NKILA (NF-KappaB Interacting LncRNA), which has a low expression in breast cancer and binds to the NF-kB / IkB complex. IkB (inhibitor of NF-kB) acts as a negative regulator of $\mathrm{NF}-\mathrm{kB}$ by binding to and sequestering NF-kB in the cytoplasm. It is considered as a major brake in NF-kB signaling [154]. NKILA binds to the NF-kB / IkB complex and directly masks the phosphorylation motifs of $\mathrm{IkB}$, which thereby inhibits IKK-induced IkB phosphorylation and NF-kB activation [133] (Figure 4).

In addition to the three patterns IncRNAs use to regulate their binding proteins, lncRNA regulate binding proteins through other way. A high expression of GAPLINC (Gastric adenocarcinoma predictive long intergenic noncoding RNA) promotes colorectal cancer invasion by binding to PSF (also known as SFPQ, splicing factor proline and glutamine rich) and NONO (non-POUdomain-containing, octamer binding) [158]. A further study found that PSF and NONO promote GAPLINC to influence cell invasion partly by increasing the expression of SNAI2 (snail family zinc finger 2), a member of the
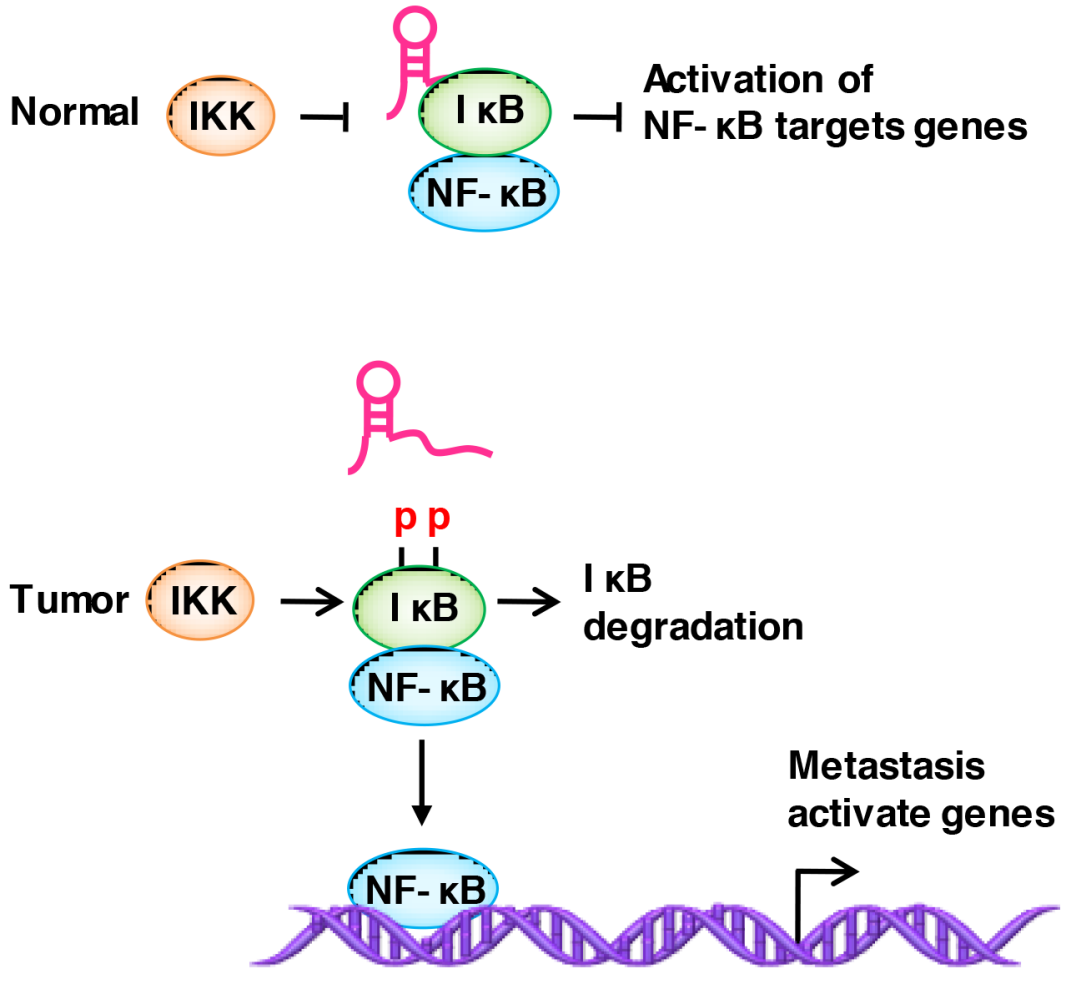

Figure 4: LncRNAs regulate the modification of binding proteins. NKILA binds to the NF-kB / IkB complex and directly masks the phosphorylation motifs of IkB, thereby inhibiting IKK-induced IkB phosphorylation and NF-kB activation. 
Table 1: Summary of IncRNAs and their binding proteins as regulators of cancer metastasis

\begin{tabular}{|c|c|c|c|c|c|}
\hline Symbol & Interaction protein & Archetype & Mechanism & Cancer type & References \\
\hline \multirow[t]{5}{*}{ HOTAIR } & PRC2 & Guide & $\begin{array}{l}\text { Histone modification; } \\
\text { Promote the transcription of ABL2, } \\
\text { SNAIL et al.) }\end{array}$ & Breast cancer & {$[130]$} \\
\hline & PRC2 (EZH2) & Guide & $\begin{array}{l}\text { Histone modification; } \\
\text { Repress E-cadherin transcription }\end{array}$ & OSCC & [133] \\
\hline & PRC2 (SUZ12) & Guide & $\begin{array}{l}\text { Histone modification; } \\
\text { Suppress promoter methylation of } \\
\text { PCDH10 }\end{array}$ & GISTs & [132] \\
\hline & PRC2 & Guide & $\begin{array}{l}\text { Histone modification; } \\
\text { HOTAIR-miR34a } \rightarrow \mathrm{HGF} / \mathrm{C}-\mathrm{Met} / \text { Snail } \\
\text { pathway }\end{array}$ & Gastric cancer & [131] \\
\hline & PRC2, LSD1 & Scaffold & Histone modification & - & {$[127]$} \\
\hline NBAT1 & PRC2 (EZH2) & Guide & $\begin{array}{l}\text { Histone modification; } \\
\text { Promote the transcription of DKK1 }\end{array}$ & Breast cancer & {$[172]$} \\
\hline DANCR & PRC2 (EZH2) & Guide & $\begin{array}{l}\text { Histone modification; } \\
\text { Suppress the transcription of TIMP } 2 / 3\end{array}$ & Prostate cancer & [173] \\
\hline LINC00511 & PRC2 (EZH2) & Guide & $\begin{array}{l}\text { Histone modification; } \\
\text { Repress p57 expression }\end{array}$ & NSCLC & {$[134]$} \\
\hline Linc-UBC1 & $\begin{array}{l}\text { PRC2 (EZH2, } \\
\quad \text { SUZ12) }\end{array}$ & Guide & Histone modification & Bladder cancer & {$[174]$} \\
\hline LncRNA-EBIC & PRC2 (EZH2) & Guide & $\begin{array}{l}\text { Histone modification; } \\
\text { Repress E-cadherin transcription }\end{array}$ & Cervical cancer & {$[175]$} \\
\hline HOXA11-AS & $\begin{array}{l}\text { EZH2, LSD1 or } \\
\text { DNMT1 }\end{array}$ & $\begin{array}{l}\text { Scaffold, } \\
\text { decoy }\end{array}$ & $\begin{array}{l}\text { Histone/DNA modification } \\
\text { "Sponge" of miR-1297 }\end{array}$ & Gastric cancer & [134] \\
\hline $\begin{array}{l}\text { LncRNA- } \\
\text { GIHCG }\end{array}$ & EZH2, DNMT1 & Scaffold & $\begin{array}{l}\text { Histone/DNA modification; } \\
\text { Silence the expression of miR } 200 \\
\text { b/a/429 }\end{array}$ & $\mathrm{HCC}$ & [135] \\
\hline AGAP2-AS1 & EZH2, LSD1 & Scaffold & $\begin{array}{l}\text { Histone modification; } \\
\text { Repress LATS2 and KLF2 transcription }\end{array}$ & NSCLC & {$[136]$} \\
\hline SChLAP1 & SWI/SNF (SNF5) & Decoy & Histone modification; & Prostate cancer & [123] \\
\hline GClnc1 & WDR5, KAT2A & Scaffold & $\begin{array}{l}\text { Histone modification; } \\
\text { Promotes SOD2 transcription }\end{array}$ & Gastric cancer & [106] \\
\hline ZEB1-AS1 & p300 & Guide & $\begin{array}{l}\text { Histone modification; } \\
\text { Activates ZEB1 transcription }\end{array}$ & Osteosarcoma & {$[142]$} \\
\hline SLNCR1 & $\mathrm{Bm} 3 \mathrm{a}, \mathrm{AR}$ & Scaffold Guide & Activates MMP9 transcription & melanoma & {$[143]$} \\
\hline BCAR4 & SNIP1, PNUTS & Scaffold & $\begin{array}{l}\text { CCL21 } \rightarrow \text { BCAR } 4 \rightarrow \text { non-canonical } \\
\text { Hedgehog/GLI2 pathway }\end{array}$ & Breast cancer & [144] \\
\hline LINC01133 & SRSF6 & Decoy & - & Colorectal cancer & [69] \\
\hline \multirow[t]{4}{*}{ MALAT1 } & PSF & Decoy & $\begin{array}{l}\text { Release oncogene PTBP2 from PSF/ } \\
\text { PTBP2 complex }\end{array}$ & Colorectal cancer & {$[145]$} \\
\hline & PRC2 (EZH2) & $\begin{array}{l}\text { Guide } \\
\text { Decoy }\end{array}$ & $\begin{array}{l}\text { Repress E-cadherin expression } \\
\text { "Sponge" of miR-1297 }\end{array}$ & Colorectal cancer & {$[176]$} \\
\hline & PRC2 (EZH2) & Guide & $\begin{array}{l}\text { Histone modification; } \\
\text { Repress PCDH10 expression }\end{array}$ & Gastric cancer & [177] \\
\hline & PRC2 (SUZ12) & $\begin{array}{l}\text { Guide } \\
\text { Signal }\end{array}$ & $\begin{array}{l}\text { Histone modification; } \\
\text { Repress E-cadherin expression }\end{array}$ & Bladder cancer & {$[68]$} \\
\hline
\end{tabular}

(Continued) 


\begin{tabular}{|c|c|c|c|c|c|}
\hline Symbol & Interaction protein & Archetype & Mechanism & Cancer type & References \\
\hline TINCR & EpCAM & Signal & $\begin{array}{l}\mathrm{TINCR} \rightarrow \text { hydrolysis of EpCAM } \rightarrow \\
\mathrm{EpICD} \rightarrow \text { Wnt } / \beta \text {-catenin pathway }\end{array}$ & Colorectal cancer & [77] \\
\hline LncRNA-LET & NF90 & Signal & $\begin{array}{l}\text { LncRNA-LET } \rightarrow \text { NF90 degradation } \\
\text {-HIF-1 } \alpha\end{array}$ & $\mathrm{HCC}$ & {$[149]$} \\
\hline LncRNA-HIT & ZEB1 & Signal & $\begin{array}{l}\text { Protect ZEB1 from degradation and } \\
\text { then Repress E-cadherin expression }\end{array}$ & NSCLC & {$[64]$} \\
\hline AOC4P & Vimentin & Signal & Enhance vimentin degradation & $\mathrm{HCC}$ & [153] \\
\hline ANCR & EZH2 & Signal & Enhance the degradation of vimentin & Breast cancer & [178] \\
\hline NKILA & $\mathrm{NF}-\kappa \mathrm{B} / \mathrm{I} \kappa \mathrm{B}$ & Signal & Blocks IkB phosphorylation & Breast cancer & [133] \\
\hline CCAT2 & $\mathrm{EZH} 2$ & Guide & $\begin{array}{l}\text { Histone modification; } \\
\text { Repress E-cadherin /LATS2 expression }\end{array}$ & Gastric cancer & {$[179]$} \\
\hline Lnc TCF7 & SWI/SNF & Guide & $\begin{array}{l}\text { Histone modification; } \\
\text { Activate } \mathrm{Wnt} / \beta \text {-catenin pathway }\end{array}$ & $\mathrm{HCC}$ & {$[78]$} \\
\hline HNF1A-AS1 & DNMT1 & Guide & $\begin{array}{l}\text { DNA modification; } \\
\text { Repress E-cadherin expression }\end{array}$ & $\begin{array}{l}\text { Lung } \\
\text { adenocarcinoma }\end{array}$ & [180] \\
\hline HULC & EZH2 & Guide & $\begin{array}{l}\text { Histone modification; } \\
\text { Repress NKD2 expression }\end{array}$ & Colorectal cancer & {$[181]$} \\
\hline
\end{tabular}

snail family of transcription factors, which promotes cell invasion, motility, and metastasis via inhibiting E-cadherin transcription and inducing EMT in several human cancers [158-161]. However, how PSF and NONO bound with GAPLINC and how they activate GAPLINC-associated genes to promote invasion is still unknown.

\section{CONCLUSION}

Currently, studies on lncRNAs have gradually become one of the hottest topics in the field of RNA biology, and lncRNAs have emerged as a versatile regulator of key pathophysiological pathways. LncRNAs have broad applications in cancer diagnosis and treatment because most of the well-studied lncRNAs are correlated with a poor prognosis in patients. The abnormal expression of lncRNAs in cancers reminds us they may be the targets of tumor diagnosis and treatment. Studies also show that lncRNAs take part in regulating cancer chemotherapy sensitivity. For example, HOTAIR activates the PI3K/Akt pathway by inhibiting the expression of miR-126 and promotes the development of cisplatin resistance in gastric cancer [162], while HOTAIR decreases chemoresistance through the activation of $\mathrm{Wnt} / \beta$-catenin signaling in ovarian cancer [80]. Other lncRNAs, such as Linc00152 [163], MALAT1 [164], UCA1 [165, 166] and lnc-ROR [167], are associated with chemotherapy sensitivity.

In addition, IncRNAs detected in the blood may represent prominent novel biomarkers for cancer diagnostics. For example, HOTAIR is detected in colorectal cancer and represents an effective negative prognostic biomarker for colorectal cancer in blood samples [168]. MALAT1 is elevated in the whole blood of metastatic lung cancer patients [169], and $H U L C$, detected in the blood, is also proposed as a diagnostic biomarker both for liver cancer and gastric cancer $[170,171]$. Studies that illuminate the molecular mechanism of the abnormal expression of lncRNAs in various cancers are helpful to improve the efficiency of clinical treatments and the diagnosis of cancer.

More and more lncRNAs, with a differential expression in tumors, are being discovered, and these lncRNAs are important regulators of genes during cell metastasis or act as regulators for other metastasisrelevant genes. Up to now, two major mechanisms have emerged for how lncRNAs regulate cancer metastasis, including (1) binding to functional proteins characteristically and then affecting the transcription of genes associated with metastasis and (2) acting as ceRNAs for miRNAs that target genes involved in metastasis regulation. There are three control modes for lncRNAs to bind to functional proteins, including (1) by regulating the localization of binding proteins, lncRNAs play a role in the chromatin and epigenetic modification and the transcription of metastasis-relevant genes, (2) lncRNAs enhance or attenuate protein stability by binding to them, and (3) lncRNAs mask or expose the modification motif to inactivate or activate the binding protein.

In summary, this review highlights the interactions between lncRNAs and their binding proteins and the mechanisms of their collaborative roles in cancer metastasis (Table 1), which provides systematic information and an evaluation of the potential of lncRNAs as prospective novel therapeutic targets in cancer. 


\section{Abbreviations}

EMT:epithelial-mesenchymal transition; MET:mesenchymal-epithelial transition; lncRNAs: long noncoding RNAs; HOTAIR :HOX transcript antisense RNA; Xist : X-inactive-specific-transcript; CeRNAs :competing endogenous RNA; MREs : miRNAs responses elements; MALAT1: metastasis associated lung adenocarcinoma transcript 1; UCA1: urothelial cancer associated 1; HULC: hepatocellular carcinoma up-regulated long non-coding RNA; NEAT1: nuclear paraspeckle assembly transcript 1; SNHG1: small nucleolar RNA host gene 1; SCHLAP1: SWI/SNF complex antagonist associated with prostate cancer 1; ANRIL: CDKN2B antisense RNA 1; GClnc1: gastric cancer-associated lncRNA 1; SOD2: dismutase 2 mitochondrial); HATs: histone acetyltransferases; SLNCR: SRA-like non-coding RNA; BCAR4: breast cancer antiestrogen resistance 4; SNIP1: SMAD nuclear interacting protein 1; SRSF6: serine and arginine rich splicing factor 6; PTBP2: polypyrimidine tract binding protein 2; TINCR: Terminal differentiation-induced lncRNA; HDAC3 : histone deacetylase 3; HIF-1 $\alpha$ : hypoxia-inducible factor 1 alpha subunit; LncRNA-HIT: HOXA transcript induced by TGF- $\beta$; NSCLC: non-small cell lung cancer; ZEB1: zinc finger E-box binding homeobox 1; AOC4P: amine oxidase, copper containing 4, pseudogene; NKILA: NF-KappaB Interacting LncRNA; IkB : inhibitor of NF-kB; GAPLINC: Gastric adenocarcinoma predictive long inergenic noncoding RNA; SNAI2: snail family zinc finger 2; OSCC: oral squamous cell carcinoma; GISTs: gastrointestinal stromal tumors; HNF1AAS1: lncRNA HNF1A-antisense 1.

\section{Authors' contributions}

FX, WX and ZZ designed and revised the manuscript. LY wrote the manuscript and drew figures. YT, YH, FW and SZ collected and related paper and created the table. CG, BX, MZ, NX, XL, YL and GL participated in the design and revise the review. All the authors read and approved the final version of the review.

\section{CONFLICTS OF INTEREST} interests.

The authors declare that they have no competing

\section{FUNDING}

This study was supported in part by grants from the National Natural Science Foundation of China (81372907, $81472531,81572787,81672683,81672993,81772928$ and 81702907), the Program of Introducing Talents of Discipline to Universities (111-2-12), the Natural Science Foundation of Hunan Province (2015JJ1022, 2016JC2035 and 2017SK2105).

\section{REFERENCES}

1. Hanahan D, Weinberg RA. Hallmarks of cancer: the next generation. Cell. 2011; 144:646-74. https://doi. org/10.1016/j.cell.2011.02.013.

2. Ferlay J, Soerjomataram I, Dikshit R, Eser S, Mathers C, Rebelo M, Parkin DM, Forman D, Bray F. Cancer incidence and mortality worldwide: sources, methods and major patterns in GLOBOCAN 2012. Int J Cancer. 2015; 136:E359-86. https://doi.org/10.1002/ijc.29210.

3. Tao ZH, Wan JL, Zeng LY, Xie L, Sun HC, Qin LX, Wang L, Zhou J, Ren ZG, Li YX, Fan J, Wu WZ. miR-612 suppresses the invasive-metastatic cascade in hepatocellular carcinoma. J Exp Med. 2013; 210:789-803. https://doi. org/10.1084/jem.20120153.

4. Gutschner T, Diederichs S. The hallmarks of cancer: a long non-coding RNA point of view. RNA Biol. 2012; 9:703-19. https://doi.org/10.4161/rna.20481.

5. Zeng Z, Zhou Y, Zhang W, Li X, Xiong W, Liu H, Fan S, Qian J, Wang L, Li Z, Shen S, Li G. Family-based association analysis validates chromosome 3 p21 as a putative nasopharyngeal carcinoma susceptibility locus. Genet Med. 2006; 8:156-60. https://doi.org/10.1097/01. gim.0000196821.87655.d0.

6. Yang Y, Zhou H, Yang Y, Li W, Zhou M, Zeng Z, Xiong W, Wu M, Huang H, Zhou Y, Peng C, Huang C, Li X, et al. Lipopolysaccharide (LPS) regulates TLR4 signal transduction in nasopharynx epithelial cell line 5-8F via NFkappaB and MAPKs signaling pathways. Mol Immunol. 2007; 44:984-92. https://doi.org/10.1016/j. molimm.2006.03.013.

7. Zeng Z, Zhou Y, Xiong W, Luo X, Zhang W, Li X, Fan S, Cao L, Tang K, Wu M, Li G. Analysis of gene expression identifies candidate molecular markers in nasopharyngeal carcinoma using microdissection and cDNA microarray. J Cancer Res Clin Oncol. 2007; 133:71-81. https:/doi. org/10.1007/s00432-006-0136-2.

8. Zeng ZY, Zhou YH, Zhang WL, Xiong W, Fan SQ, Li XL, Luo XM, Wu MH, Yang YX, Huang C, Cao L, Tang K, Qian J, et al. Gene expression profiling of nasopharyngeal carcinoma reveals the abnormally regulated Wnt signaling pathway. Hum Pathol. 2007; 38:120-33. https://doi. org/10.1016/j.humpath.2006.06.023.

9. Zhou Y, Zeng Z, Zhang W, Xiong W, Wu M, Tan Y, Yi W, Xiao L, Li X, Huang C, Cao L, Tang K, Li X, et al. Lactotransferrin: a candidate tumor suppressor-Deficient expression in human nasopharyngeal carcinoma and inhibition of NPC cell proliferation by modulating the mitogen-activated protein kinase pathway. Int J Cancer. 2008; 123:2065-72. https://doi.org/10.1002/ijc.23727.

10. Thiery JP, Acloque H, Huang RY, Nieto MA. Epithelialmesenchymal transitions in development and disease. Cell. 2009; 139:871-90. https://doi.org/10.1016/j. cell.2009.11.007. 
11. Song Y, Li X, Zeng Z, Li Q, Gong Z, Liao Q, Li X, Chen P, Xiang B, Zhang W, Xiong F, Zhou Y, Zhou M, et al. Epstein-Barr virus encoded miR-BART11 promotes inflammation-induced carcinogenesis by targeting FOXP1. Oncotarget. 2016; 7:36783-99. https://doi.org/10.18632/ oncotarget.9170.

12. Xiao K, Yu Z, Li X, Li X, Tang K, Tu C, Qi P, Liao Q, Chen P, Zeng Z, Li G, Xiong W. Genome-wide analysis of epstein-barr virus (EBV) integration and strain in C666-1 and raji cells. J Cancer. 2016; 7:214-24. https://doi. org/10.7150/jca.13150.

13. Zeng Z, Fan S, Zhang X, Li S, Zhou M, Xiong W, Tan M, Zhang W, Li G. Epstein-Barr virus-encoded small RNA 1 (EBER-1) could predict good prognosis in nasopharyngeal carcinoma. Clin Transl Oncol. 2016; 18:206-11. https://doi. org/10.1007/s12094-015-1354-3.

14. Tang Y, He Y, Shi L, Yang L, Wang J, Lian Y, Fan C, Zhang P, Guo C, Zhang S, Gong Z, Li X, Xiong F, et al. Co-expression of AFAP1-AS1 and PD-1 predicts poor prognosis in nasopharyngeal carcinoma. Oncotarget. 2017; 8:39001-11. https://doi.org/10.18632/oncotarget.16545.

15. Wang M, Zhao J, Zhang L, Wei F, Lian Y, Wu Y, Gong Z, Zhang S, Zhou J, Cao K, Li X, Xiong W, Li G, et al. Role of tumor microenvironment in tumorigenesis. J Cancer. 2017; 8:761-73. https://doi.org/10.7150/jca.17648.

16. Simpson CD, Anyiwe K, Schimmer AD. Anoikis resistance and tumor metastasis. Cancer Lett. 2008; 272:177-85. https://doi.org/10.1016/j.canlet.2008.05.029.

17. Wang Y, Mo Y, Gong Z, Yang X, Yang M, Zhang S, Xiong F, Xiang B, Zhou M, Liao Q, Zhang W, Li X, Li X, et al. Circular RNAs in human cancer. Mol Cancer. 2017; 16:25. https://doi.org/10.1186/s12943-017-0598-7.

18. Wang Y, Xue D, Li Y, Pan X, Zhang X, Kuang B, Zhou M, Li X, Xiong W, Li G, Zeng Z, Yang T. The long noncoding RNA MALAT-1 is a novel biomarker in various cancers: a metaanalysis based on the geo database and literature. J Cancer. 2016; 7:991-1001. https://doi.org/10.7150/jca.14663.

19. Gong Z, Zhang S, Zhang W, Huang H, Li Q, Deng H, Ma J, Zhou M, Xiang J, Wu M, Li X, Xiong W, Li X, et al. Long non-coding RNAs in cancer. Sci China Life Sci. 2012; 55:1120-24. https://doi.org/10.1007/s11427-012-4413-9.

20. Yang L, Tang Y, He Y, Wang Y, Lian Y, Xiong F, Shi L, Zhang S, Gong Z, Zhou Y, Liao Q, Zhou M, Li X, et al. High Expression of LINC01420 indicates an unfavorable prognosis and modulates cell migration and invasion in nasopharyngeal carcinoma. J Cancer. 2017; 8:97-103. https://doi.org/10.7150/jca.16819.

21. Yu J, Liu Y, Gong Z, Zhang S, Guo C, Li X, Tang Y, Yang L, He Y, Wei F, Wang Y, Liao Q, Zhang W, et al. Overexpression long non-coding RNA LINC00673 is associated with poor prognosis and promotes invasion and metastasis in tongue squamous cell carcinoma. Oncotarget. 2017; 8:16621-32. https://doi.org/10.18632/ oncotarget. 14200 .
22. Yu J, Liu Y, Guo C, Zhang S, Gong Z, Tang Y, Yang L, He Y, Lian Y, Li X, Deng H, Liao Q, Li X, et al. Upregulated long non-coding RNA LINC00152 expression is associated with progression and poor prognosis of tongue squamous cell carcinoma. J Cancer. 2017; 8:523-30. https://doi. org/10.7150/jca. 17510.

23. Prensner JR, Chinnaiyan AM. The emergence of lncRNAs in cancer biology. Cancer Discov. 2011; 1:391-407. https:// doi.org/10.1158/2159-8290.CD-11-0209.

24. Niland CN, Merry CR, Khalil AM. Emerging roles for long non-coding RNAs in cancer and neurological disorders. Front Genet. 2012; 3:25. https://doi.org/10.3389/ fgene.2012.00025.

25. Li CH, Chen Y. Insight into the role of long noncoding RNA in cancer development and progression. Int Rev Cell Mol Biol. 2016; 326:33-65. https://doi.org/10.1016/ bs.ircmb.2016.04.001.

26. Zhou Y, Liao Q, Li X, Wang H, Wei F, Chen J, Yang J, Zeng Z, Guo X, Chen P, Zhang W, Tang K, Li X, et al. HYOU1, regulated by LPLUNC1, is up-regulated in nasopharyngeal carcinoma and associated with poor prognosis. J Cancer. 2016; 7:367-76. https://doi.org/10.7150/jca.13695.

27. Tang Y, Wang J, Lian Y, Fan C, Zhang P, Wu Y, Li X, Xiong F, Li X, Li G, Xiong W, Zeng Z. Linking long non-coding RNAs and SWI/SNF complexes to chromatin remodeling in cancer. Mol Cancer. 2017; 16:42. https://doi.org/10.1186/ s12943-017-0612-0.

28. Tu C, Zeng Z, Qi P, Li X, Yu Z, Guo C, Xiong F, Xiang B, Zhou M, Gong Z, Liao Q, Yu J, He Y, et al. Genomewide analysis of eighteen epstein-barr viruses isolated from primary nasopharyngeal carcinoma biopsies. J Virol. 2017; 91:e00301-17. https://doi.org/10.1128/JVI.00301-17.

29. Fan C, Tang Y, Wang J, Xiong F, Guo C, Wang Y, Zhang S, Gong Z, Wei F, Yang L, He Y, Zhou M, Li X, et al. Role of long non-coding RNAs in glucose metabolism in cancer. Mol Cancer. 2017; 16:130. https://doi.org/10.1186/ s12943-017-0699-3.

30. Zeng Z, Huang H, Zhang W, Xiang B, Zhou M, Zhou Y, Ma J, Yi M, Li X, Li X, Xiong W, Li G. Nasopharyngeal carcinoma: advances in genomics and molecular genetics. Sci China Life Sci. 2011; 54:966-75. https://doi. org/10.1007/s11427-011-4223-5.

31. Liao Q, Guo X, Li X, Xiong W, Li X, Yang J, Chen P, Zhang W, Yu H, Tang H, Deng M, Liang F, Wu M, et al. Prohibitin is an important biomarker for nasopharyngeal carcinoma progression and prognosis. Eur J Cancer Prev. 2013; 22:68-76. https://doi.org/10.1097/CEJ.0b013 e328354d351.

32. Yang Y, Liao Q, Wei F, Li X, Zhang W, Fan S, Shi L, Li X, Gong Z, Ma J, Zhou M, Xiang J, Peng S, et al. LPLUNC1 inhibits nasopharyngeal carcinoma cell growth via downregulation of the MAP kinase and cyclin D1/E2F pathways. PLoS One. 2013; 8:e62869. https://doi.org/10.1371/journal. pone. 0062869 . 
33. Liao Q, Zeng Z, Guo X, Li X, Wei F, Zhang W, Li X, Chen P, Liang F, Xiang B, Ma J, Wu M, Tang H, et al. LPLUNC1 suppresses IL-6-induced nasopharyngeal carcinoma cell proliferation via inhibiting the Stat3 activation. Oncogene. 2014; 33:2098-109. https://doi.org/10.1038/onc.2013.161.

34. Zeng Z, Huang H, Huang L, Sun M, Yan Q, Song Y, Wei F, Bo H, Gong Z, Zeng Y, Li Q, Zhang W, Li X, et al. Regulation network and expression profiles of EpsteinBarr virus-encoded microRNAs and their potential target host genes in nasopharyngeal carcinomas. Sci China Life Sci. 2014; 57:315-26. https://doi.org/10.1007/ s11427-013-4577-y.

35. Zhang W, Zeng Z, Wei F, Chen P, Schmitt DC, Fan S, Guo X, Liang F, Shi L, Liu Z, Zhang Z, Xiang B, Zhou M, et al. SPLUNC1 is associated with nasopharyngeal carcinoma prognosis and plays an important role in all-trans-retinoic acid-induced growth inhibition and differentiation in nasopharyngeal cancer cells. FEBS J. 2014; 281:4815-29. https://doi.org/10.1111/febs.13020.

36. Zhang W, Fan S, Zou G, Shi L, Zeng Z, Ma J, Zhou Y, Li X, Zhang X, Li X, Tan M, Xiong W, Li G. Lactotransferrin could be a novel independent molecular prognosticator of nasopharyngeal carcinoma. Tumour Biol. 2015; 36:675-83. https://doi.org/10.1007/s13277-014-2650-1.

37. Lee JM, Dedhar S, Kalluri R, Thompson EW. The epithelial-mesenchymal transition: new insights in signaling, development, and disease. J Cell Biol. 2006; 172:973-81. https://doi.org/10.1083/jcb.200601018.

38. Zhang W, Zeng Z, Fan S, Wang J, Yang J, Zhou Y, Li X, Huang D, Liang F, Wu M, Tang K, Cao L, Li X, et al. Evaluation of the prognostic value of TGF- $\beta$ superfamily type I receptor and TGF- $\beta$ type II receptor expression in nasopharyngeal carcinoma using high-throughput tissue microarrays. J Mol Histol. 2012; 43:297-306. https://doi. org/10.1007/s10735-012-9392-4.

39. Li Q, Chen P, Zeng Z, Liang F, Song Y, Xiong F, Li X, Gong Z, Zhou M, Xiang B, Peng C, Li X, Chen X, et al. Yeast two-hybrid screening identified WDR77 as a novel interacting partner of TSC22D2. Tumour Biol. 2016; 37:12503-12. https://doi.org/10.1007/s13277-016-5113-z.

40. Liang F, Li Q, Li X, Li Z, Gong Z, Deng H, Xiang B, Zhou M, Li X, Li G, Zeng Z, Xiong W. TSC22D2 interacts with PKM2 and inhibits cell growth in colorectal cancer. Int J Oncol. 2016; 49:1046-56. https://doi.org/10.3892/ ijo.2016.3599.

41. Xu K, Xiong W, Zhou M, Wang H, Yang J, Li X, Chen P, Liao Q, Deng H, Li X, Li G, Zeng Z. Integrating ChIPsequencing and digital gene expression profiling to identify BRD7 downstream genes and construct their regulating network. Mol Cell Biochem. 2016; 411:57-71. https://doi. org/10.1007/s11010-015-2568-y.

42. Kalluri R, Weinberg RA. The basics of epithelialmesenchymal transition. J Clin Invest. 2009; 119:1420-28. https://doi.org/10.1172/JCI39104.
43. Nieto MA. The ins and outs of the epithelial to mesenchymal transition in health and disease. Annu Rev Cell Dev Biol. 2011; 27:347-76. https://doi.org/10.1146/ annurev-cellbio-092910-154036.

44. Goswami MT, Reka AK, Kurapati H, Kaza V, Chen J, Standiford TJ, Keshamouni VG. Regulation of complementdependent cytotoxicity by TGF- $\beta$-induced epithelialmesenchymal transition. Oncogene. 2016; 35:1888-98. https://doi.org/10.1038/onc.2015.258.

45. Tse JC, Kalluri R. Mechanisms of metastasis: epithelialto-mesenchymal transition and contribution of tumor microenvironment. J Cell Biochem. 2007; 101:816-29. https://doi.org/10.1002/jcb.21215.

46. Zhou B, Liu Y, Kahn M, Ann DK, Han A, Wang H, Nguyen C, Flodby P, Zhong Q, Krishnaveni MS, Liebler JM, Minoo $\mathrm{P}$, Crandall ED, et al. Interactions between $\beta$-catenin and transforming growth factor- $\beta$ signaling pathways mediate epithelial-mesenchymal transition and are dependent on the transcriptional co-activator cAMP-response elementbinding protein (CREB)-binding protein (CBP). J Biol Chem. 2012; 287:7026-38. https://doi.org/10.1074/jbc. M111.276311.

47. Thiery JP. Epithelial-mesenchymal transitions in development and pathologies. Curr Opin Cell Biol. 2003; 15:740-46. https://doi.org/10.1016/j.ceb.2003.10.006.

48. Duan Z, Zheng H, Liu H, Li M, Tang M, Weng X, Yi W, Bode AM, Cao Y. AID expression increased by TNF- $\alpha$ is associated with class switch recombination of Ig $\alpha$ gene in cancers. Cell Mol Immunol. 2016; 13:484-91. https://doi. org/10.1038/cmi.2015.26.

49. Duan Z, Zheng H, Xu S, Jiang Y, Liu H, Li M, Hu D, Li W, Bode AM, Dong Z, Cao Y. Activation of the Ig I $\alpha 1$ promoter by the transcription factor Ets-1 triggers Ig I $\alpha 1-\mathrm{C} \alpha 1$ germline transcription in epithelial cancer cells. Cell Mol Immunol. 2014; 11:197-205. https://doi.org/10.1038/ cmi.2013.52.

50. Hu D, Duan Z, Li M, Jiang Y, Liu H, Zheng H, Li L, Bode AM, Dong Z, Cao Y. Heterogeneity of aberrant immunoglobulin expression in cancer cells. Cell Mol Immunol. 2011; 8:479-85. https://doi.org/10.1038/ cmi.2011.25.

51. Hu D, Zheng H, Liu H, Li M, Ren W, Liao W, Duan Z, Li L, Cao Y. Immunoglobulin expression and its biological significance in cancer cells. Cell Mol Immunol. 2008; 5:319-24. https://doi.org/10.1038/cmi.2008.39.

52. Li M, Zheng H, Duan Z, Liu H, Hu D, Bode A, Dong Z, Cao Y. Promotion of cell proliferation and inhibition of ADCC by cancerous immunoglobulin expressed in cancer cell lines. Cell Mol Immunol. 2012; 9:54-61. https://doi. org/10.1038/cmi.2011.40.

53. Zhao R, Liu Y, Wang H, Yang J, Niu W, Fan S, Xiong W, Ma J, Li X, Phillips JB, Tan M, Qiu Y, Li G, et al. BRD7 plays an anti-inflammatory role during early acute inflammation by inhibiting activation of the NF- $\mathrm{KB}$ 
signaling pathway. Cell Mol Immunol. 2017; 14:830-841. https://doi.org/10.1038/cmi.2016.31 PMID:27374794.

54. Zheng Y, Zhang W, Ye Q, Zhou Y, Xiong W, He W, Deng M, Zhou M, Guo X, Chen P, Fan S, Liu X, Wang $Z$, et al. Inhibition of Epstein-Barr virus infection by lactoferrin. J Innate Immun. 2012; 4:387-98. https://doi. org/10.1159/000336178.

55. Ding L, Li L, Yang J, Zhou S, Li W, Tang M, Shi Y, Yi W, Cao Y. Latent membrane protein 1 encoded by Epstein-Barr virus induces telomerase activity via p16INK4A/Rb/E2F1 and JNK signaling pathways. J Med Virol. 2007; 79:115363. https://doi.org/10.1002/jmv.20896.

56. Yu H, Lu J, Zuo L, Yan Q, Yu Z, Li X, Huang J, Zhao L, Tang H, Luo Z, Liao Q, Zeng Z, Zhang J, et al. EpsteinBarr virus downregulates microRNA 203 through the oncoprotein latent membrane protein 1: a contribution to increased tumor incidence in epithelial cells. J Virol. 2012; 86:3088-99. https://doi.org/10.1128/JVI.05901-11.

57. Yu Z, Lu J, Yu H, Yan Q, Zuo L, Li G. A precise excision of the complete Epstein-Barr virus genome in a plasmid based on a bacterial artificial chromosome. J Virol Methods. 2011; 176:103-07. https://doi.org/10.1016/j.jviromet.2011.06.015.

58. Zheng H, Li M, Ren W, Zeng L, Liu HD, Hu D, Deng X, Tang M, Shi Y, Gong J, Cao Y. Expression and secretion of immunoglobulin alpha heavy chain with diverse VDJ recombinations by human epithelial cancer cells. Mol Immunol. 2007; 44:2221-27. https://doi.org/10.1016/j. molimm.2006.11.010.

59. Luo C, Wang JJ, Li YH, Hu JY, Li GC. Immunogenicity and efficacy of a DNA vaccine encoding a human anti-idiotype single chain antibody against nasopharyngeal carcinoma. Vaccine. 2010; 28:2769-74. https://doi.org/10.1016/j. vaccine.2010.01.033.

60. Li L, Li Z, Zhou S, Xiao L, Guo L, Tao Y, Tang M, Shi Y, Li W, Yi W, Cao Y. Ubiquitination of MDM2 modulated by Epstein-Barr virus encoded latent membrane protein 1. Virus Res. 2007; 130:275-80. https://doi.org/10.1016/j. virusres.2007.05.013.

61. Moustakas A, Heldin CH. Mechanisms of TGFbeta-induced epithelial-mesenchymal transition. J Clin Med. 2016; 5:E63. https://doi.org/10.3390/jcm5070063.

62. Moustakas A, Heldin P. TGF $\beta$ and matrix-regulated epithelial to mesenchymal transition. Biochim Biophys Acta. 2014; 1840:2621-34. https://doi.org/10.1016/j. bbagen.2014.02.004.

63. Richards EJ, Zhang G, Li ZP, Permuth-Wey J, Challa S, Li Y, Kong W, Dan S, Bui MM, Coppola D, Mao WM, Sellers TA, Cheng JQ. Long non-coding RNAs (LncRNA) regulated by transforming growth factor (TGF) $\beta$ : LncRNAhit-mediated TGF $\beta$-induced epithelial to mesenchymal transition in mammary epithelia. J Biol Chem. 2015; 290:6857-67. https://doi.org/10.1074/jbc.M114.610915.

64. Jia X, Wang Z, Qiu L, Yang Y, Wang Y, Chen Z, Liu Z, Yu L. Upregulation of LncRNA-HIT promotes migration and invasion of non-small cell lung cancer cells by association with ZEB1. Cancer Med. 2016; 5:3555-63. https://doi. org/10.1002/cam4.948.

65. Yuan JH, Yang F, Wang F, Ma JZ, Guo YJ, Tao QF, Liu F, Pan W, Wang TT, Zhou CC, Wang SB, Wang YZ, Yang $\mathrm{Y}$, et al. A long noncoding RNA activated by TGF- $\beta$ promotes the invasion-metastasis cascade in hepatocellular carcinoma. Cancer Cell. 2014; 25:666-81. https://doi. org/10.1016/j.ccr.2014.03.010.

66. Yue B, Qiu S, Zhao S, Liu C, Zhang D, Yu F, Peng Z, Yan D. LncRNA-ATB mediated E-cadherin repression promotes the progression of colon cancer and predicts poor prognosis. J Gastroenterol Hepatol. 2016; 31:595-603. https://doi. org/10.1111/jgh.13206.

67. Zhuang J, Lu Q, Shen B, Huang X, Shen L, Zheng X, Huang R, Yan J, Guo H. TGF $\beta 1$ secreted by cancer-associated fibroblasts induces epithelial-mesenchymal transition of bladder cancer cells through lncRNA-ZEB2NAT. Sci Rep. 2015; 5:11924. https://doi.org/10.1038/srep11924.

68. Fan Y, Shen B, Tan M, Mu X, Qin Y, Zhang F, Liu Y. TGF$\beta$-induced upregulation of malat1 promotes bladder cancer metastasis by associating with suz12. Clin Cancer Res. 2014; 20:1531-41. https://doi.org/10.1158/1078-0432. CCR-13-1455.

69. Kong J, Sun W, Li C, Wan L, Wang S, Wu Y, Xu E, Zhang H, Lai M. Long non-coding RNA LINC01133 inhibits epithelial-mesenchymal transition and metastasis in colorectal cancer by interacting with SRSF6. Cancer Lett. 2016; 380:476-84. https://doi.org/10.1016/j. canlet.2016.07.015.

70. Zhang K, Zhang J, Han L, Pu P, Kang C. Wnt/beta-catenin signaling in glioma. J Neuroimmune Pharmacol. 2012; 7:740-49. https://doi.org/10.1007/s11481-012-9359-y.

71. Ashihara E, Takada T, Maekawa T. Targeting the canonical $\mathrm{Wnt} / \beta$-catenin pathway in hematological malignancies. Cancer Sci. 2015; 106:665-71. https://doi.org/10.1111/ cas. 12655 .

72. Peng Y, Zhang X, Feng X, Fan X, Jin Z. The crosstalk between microRNAs and the $\mathrm{Wnt} / \beta$-catenin signaling pathway in cancer. Oncotarget. 2017; 8:14089-106. https:// doi.org/10.18632/oncotarget.12923.

73. Pai SG, Carneiro BA, Mota JM, Costa R, Leite CA, Barroso-Sousa R, Kaplan JB, Chae YK, Giles FJ. Wnt/betacatenin pathway: modulating anticancer immune response. J Hematol Oncol. 2017; 10:101. https://doi.org/10.1186/ s13045-017-0471-6.

74. Ge XS, Ma HJ, Zheng XH, Ruan HL, Liao XY, Xue WQ, Chen YB, Zhang Y, Jia WH. HOTAIR, a prognostic factor in esophageal squamous cell carcinoma, inhibits WIF-1 expression and activates Wnt pathway. Cancer Sci. 2013; 104:1675-82. https://doi.org/10.1111/cas.12296.

75. Vassallo I, Zinn P, Lai M, Rajakannu P, Hamou MF, Hegi ME. WIF1 re-expression in glioblastoma inhibits migration through attenuation of non-canonical WNT signaling by 
downregulating the lncRNA MALAT1. Oncogene. 2016; 35:12-21. https://doi.org/10.1038/onc.2015.61.

76. Luo M, Li Z, Wang W, Zeng Y, Liu Z, Qiu J. Long noncoding RNA H19 increases bladder cancer metastasis by associating with EZH2 and inhibiting E-cadherin expression. Cancer Lett. 2013; 333:213-21. https://doi. org/10.1016/j.canlet.2013.01.033.

77. Zhang ZY, Lu YX, Zhang ZY, Chang YY, Zheng L, Yuan L, Zhang F, Hu YH, Zhang WJ, Li XN. Loss of TINCR expression promotes proliferation, metastasis through activating EpCAM cleavage in colorectal cancer. Oncotarget. 2016; 7:22639-49. https://doi.org/10.18632/ oncotarget.8141.

78. Wang Y, He L, Du Y, Zhu P, Huang G, Luo J, Yan X, Ye B, Li C, Xia P, Zhang G, Tian Y, Chen R, et al. The long noncoding RNA lncTCF7 promotes self-renewal of human liver cancer stem cells through activation of Wnt signaling. Cell Stem Cell. 2015; 16:413-25. https://doi.org/10.1016/j. stem.2015.03.003.

79. Wu XS, Wang XA, Wu WG, Hu YP, Li ML, Ding Q, Weng H, Shu YJ, Liu TY, Jiang L, Cao Y, Bao RF, Mu JS, et al. MALAT1 promotes the proliferation and metastasis of gallbladder cancer cells by activating the ERK/MAPK pathway. Cancer Biol Ther. 2014; 15:806-14. https://doi. org/10.4161/cbt.28584.

80. Li J, Yang S, Su N, Wang Y, Yu J, Qiu H, He X. Erratum to: overexpression of long non-coding RNA HOTAIR leads to chemoresistance by activating the $\mathrm{Wnt} / \beta$-catenin pathway in human ovarian cancer. Tumour Biol. 2015; 36:9093-94. https://doi.org/10.1007/s13277-015-4210-8.

81. Zhou J, Zhi X, Wang L, Wang W, Li Z, Tang J, Wang J, Zhang Q, Xu Z. Linc00152 promotes proliferation in gastric cancer through the EGFR-dependent pathway. J Exp Clin Cancer Res. 2015; 34:135. https://doi.org/10.1186/ s13046-015-0250-6.

82. Xu S, Sui S, Zhang J, Bai N, Shi Q, Zhang G, Gao S, You Z, Zhan C, Liu F, Pang D. Downregulation of long noncoding RNA MALAT1 induces epithelial-to-mesenchymal transition via the PI3K-AKT pathway in breast cancer. Int $\mathrm{J}$ Clin Exp Pathol. 2015; 8:4881-91.

83. Dong Y, Liang G, Yuan B, Yang C, Gao R, Zhou X. MALAT1 promotes the proliferation and metastasis of osteosarcoma cells by activating the PI3K/Akt pathway. Tumour Biol. 2015; 36:1477-86. https://doi.org/10.1007/ s13277-014-2631-4.

84. Jia M, Jiang L, Wang YD, Huang JZ, Yu M, Xue HZ. lincRNA-p21 inhibits invasion and metastasis of hepatocellular carcinoma through Notch signaling-induced epithelial-mesenchymal transition. Hepatol Res. 2016; 46:1137-44. https://doi.org/10.1111/hepr.12659.

85. Audas TE, Lee S. Stressing out over long noncoding RNA. Biochim Biophys Acta. 2016; 1859:184-91. https://doi. org/10.1016/j.bbagrm.2015.06.010.
86. Pan L, Liang W, Fu M, Huang ZH, Li X, Zhang W, Zhang P, Qian H, Jiang PC, Xu WR, Zhang X. Exosomes-mediated transfer of long noncoding RNA ZFAS1 promotes gastric cancer progression. J Cancer Res Clin Oncol. 2017; 143:991-1004. https://doi.org/10.1007/s00432-017-2361-2.

87. Renganathan A, Kresoja-Rakic J, Echeverry N, Ziltener G, Vrugt B, Opitz I, Stahel RA, Felley-Bosco E. GAS5 long non-coding RNA in malignant pleural mesothelioma. Mol Cancer. 2014; 13:119. https://doi. org/10.1186/1476-4598-13-119.

88. Zhou M, Hou Y, Yang G, Zhang H, Tu G, Du YE, Wen S, Xu L, Tang X, Tang S, Yang L, Cui X, Liu M. LncRNA-Hh strengthen cancer stem cells generation in twist-positive breast cancer via activation of hedgehog signaling pathway. Stem Cells. 2016; 34:55-66. https://doi.org/10.1002/stem.2219.

89. Mercer TR, Mattick JS. Structure and function of long noncoding RNAs in epigenetic regulation. Nat Struct Mol Biol. 2013; 20:300-07. https://doi.org/10.1038/nsmb.2480.

90. Wang KC, Chang HY. Molecular mechanisms of long noncoding RNAs. Mol Cell. 2011; 43:904-14. https://doi. org/10.1016/j.molcel.2011.08.018.

91. Huarte M, Guttman M, Feldser D, Garber M, Koziol MJ, Kenzelmann-Broz D, Khalil AM, Zuk O, Amit I, Rabani M, Attardi LD, Regev A, Lander ES, et al. A large intergenic noncoding RNA induced by p53 mediates global gene repression in the p53 response. Cell. 2010; 142:409-19. https://doi.org/10.1016/j.cell.2010.06.040.

92. Rinn JL, Kertesz M, Wang JK, Squazzo SL, Xu X, Brugmann SA, Goodnough LH, Helms JA, Farnham PJ, Segal E, Chang HY. Functional demarcation of active and silent chromatin domains in human HOX loci by noncoding RNAs. Cell. 2007; 129:1311-23. https://doi.org/10.1016/j. cell.2007.05.022.

93. Tian D, Sun S, Lee JT. The long noncoding RNA, Jpx, is a molecular switch for $\mathrm{X}$ chromosome inactivation. Cell. 2010; 143:390-403. https://doi.org/10.1016/j. cell.2010.09.049.

94. Salmena L, Poliseno L, Tay Y, Kats L, Pandolfi PP. A ceRNA hypothesis: the Rosetta Stone of a hidden RNA language? Cell. 2011; 146:353-58. https://doi.org/10.1016/j. cell.2011.07.014.

95. Sen R, Ghosal S, Das S, Balti S, Chakrabarti J. Competing endogenous RNA: the key to posttranscriptional regulation. Sci World J. 2014; 2014:896206. https://doi. org/10.1155/2014/896206.

96. Yan L, Zhou J, Gao Y, Ghazal S, Lu L, Bellone S, Yang Y, Liu N, Zhao X, Santin AD, Taylor H, Huang Y. Regulation of tumor cell migration and invasion by the H19/let-7 axis is antagonized by metformin-induced DNA methylation. Oncogene. 2015; 34:3076-84. https://doi.org/10.1038/onc.2014.236.

97. Ma C, Nong K, Zhu H, Wang W, Huang X, Yuan Z, Ai K. H19 promotes pancreatic cancer metastasis by derepressing let-7's suppression on its target HMGA2-mediated EMT. 
Tumour Biol. 2014; 35:9163-69. https://doi.org/10.1007/ s13277-014-2185-5.

98. Li M, Chen H, Zhao Y, Gao S, Cheng C. H19 functions as a ceRNA in promoting metastasis through decreasing miR-200s activity in osteosarcoma. DNA Cell Biol. 2016; 35:235-40. https://doi.org/10.1089/dna.2015.3171.

99. Li X, Lin Y, Yang X, Wu X, He X. Long noncoding RNA H19 regulates EZH2 expression by interacting with miR-630 and promotes cell invasion in nasopharyngeal carcinoma. Biochem Biophys Res Commun. 2016; 473:913-19. https://doi.org/10.1016/j.bbrc.2016.03.150.

100. Song B, Guan Z, Liu F, Sun D, Wang K, Qu H. Long non-coding RNA HOTAIR promotes HLA-G expression via inhibiting miR-152 in gastric cancer cells. Biochem Biophys Res Commun. 2015; 464:807-13. https://doi. org/10.1016/j.bbrc.2015.07.040.

101. Liu XH, Sun M, Nie FQ, Ge YB, Zhang EB, Yin DD, Kong R, Xia R, Lu KH, Li JH, De W, Wang KM, Wang ZX. Lnc RNA HOTAIR functions as a competing endogenous RNA to regulate HER2 expression by sponging miR-331-3p in gastric cancer. Mol Cancer. 2014; 13:92. https://doi. org/10.1186/1476-4598-13-92.

102. Zhang Z, Cheng J, Wu Y, Qiu J, Sun Y, Tong X. LncRNA HOTAIR controls the expression of Rab22a by sponging miR-373 in ovarian cancer. Mol Med Rep. 2016; 14:246572. https://doi.org/10.3892/mmr.2016.5572.

103. Sun L, Sun P, Zhou QY, Gao X, Han Q. Long noncoding RNA MALAT1 promotes uveal melanoma cell growth and invasion by silencing of miR-140. Am J Transl Res. 2016; 8:3939-46.

104. Xiao H, Tang K, Liu P, Chen K, Hu J, Zeng J, Xiao W, Yu G, Yao W, Zhou H, Li H, Pan Y, Li A, et al. LncRNA MALAT1 functions as a competing endogenous RNA to regulate ZEB2 expression by sponging miR-200s in clear cell kidney carcinoma. Oncotarget. 2015; 6:38005-15. https://doi.org/10.18632/oncotarget.5357.

105. Tan X, Huang Z, Li X. Long non-coding RNA MALAT1 interacted with miR-204 to modulates human hilar cholangiocarcinoma proliferation, migration and invasion by targeting CXCR4. J Cell Biochem. 2017; 118:3643-53. https://doi.org/10.1002/jcb.25862.

106. Sun CC, Li SJ, Li G, Hua RX, Zhou XH, Li DJ. Long intergenic noncoding RNA 00511 acts as an oncogene in non-small-cell lung cancer by binding to EZH2 and suppressing p57. Mol Ther Nucleic Acids. 2016; 5:e385. https://doi.org/10.1038/mtna.2016.94.

107. Wang SH, Zhang WJ, Wu XC, Zhang MD, Weng MZ, Zhou D, Wang JD, Quan ZW. Long non-coding RNA Malat1 promotes gallbladder cancer development by acting as a molecular sponge to regulate miR-206. Oncotarget. 2016; 7:37857-67. https://doi.org/10.18632/oncotarget.9347.

108. Xue M, Pang H, Li X, Li H, Pan J, Chen W. Long noncoding RNA urothelial cancer-associated 1 promotes bladder cancer cell migration and invasion by way of the
hsa-miR-145-ZEB1/2-FSCN1 pathway. Cancer Sci. 2016; 107:18-27. https://doi.org/10.1111/cas.12844.

109. Nie W, Ge HJ, Yang XQ, Sun X, Huang H, Tao X, Chen WS, Li B. LncRNA-UCA1 exerts oncogenic functions in non-small cell lung cancer by targeting miR-193a-3p. Cancer Lett. 2016; 371:99-106. https://doi.org/10.1016/j. canlet.2015.11.024.

110. Wang F, Ying HQ, He BS, Pan YQ, Deng QW, Sun HL, Chen J, Liu X, Wang SK. Upregulated IncRNA-UCA1 contributes to progression of hepatocellular carcinoma through inhibition of miR-216b and activation of FGFR1/ ERK signaling pathway. Oncotarget. 2015; 6:7899-917. https://doi.org/10.18632/oncotarget.3219.

111. Yang Y, Jiang Y, Wan Y, Zhang L, Qiu J, Zhou S, Cheng W. UCA1 functions as a competing endogenous RNA to suppress epithelial ovarian cancer metastasis. Tumour Biol. 2016; 37:10633-41. https://doi.org/10.1007/ s13277-016-4917-1.

112. Zhuang LK, Yang YT, Ma X, Han B, Wang ZS, Zhao QY, Wu LQ, Qu ZQ. MicroRNA-92b promotes hepatocellular carcinoma progression by targeting Smad7 and is mediated by long non-coding RNA XIST. Cell Death Dis. 2016; 7:e2203. https://doi.org/10.1038/cddis.2016.100.

113. Chen DL, Ju HQ, Lu YX, Chen LZ, Zeng ZL, Zhang DS, Luo HY, Wang F, Qiu MZ, Wang DS, Xu DZ, Zhou ZW, Pelicano $\mathrm{H}$, et al. Long non-coding RNA XIST regulates gastric cancer progression by acting as a molecular sponge of miR-101 to modulate EZH2 expression. J Exp Clin Cancer Res. 2016; 35:142. https://doi.org/10.1186/ s13046-016-0420-1.

114. Li SP, Xu HX, Yu Y, He JD, Wang Z, Xu YJ, Wang CY, Zhang HM, Zhang RX, Zhang JJ, Yao Z, Shen ZY. LncRNA HULC enhances epithelial-mesenchymal transition to promote tumorigenesis and metastasis of hepatocellular carcinoma via the miR-200a-3p/ZEB1 signaling pathway. Oncotarget. 2016; 7:42431-46. https://doi.org/10.18632/ oncotarget. 9883 .

115. Eades G, Wolfson B, Zhang Y, Li Q, Yao Y, Zhou Q. lincRNA-RoR and miR-145 regulate invasion in triplenegative breast cancer via targeting ARF6. Mol Cancer Res. 2015; 13:330-38. https://doi.org/10.1158/1541-7786. MCR-14-0251.

116. Liu F, Yuan JH, Huang JF, Yang F, Wang TT, Ma JZ, Zhang L, Zhou CC, Wang F, Yu J, Zhou WP, Sun SH. Long noncoding RNA FTX inhibits hepatocellular carcinoma proliferation and metastasis by binding MCM2 and miR-374a. Oncogene. 2016; 35:5422-34. https://doi. org/10.1038/onc.2016.80.

117. Li JH, Zhang SQ, Qiu XG, Zhang SJ, Zheng SH, Zhang DH. Long non-coding RNA NEAT1 promotes malignant progression of thyroid carcinoma by regulating miRNA214. Int J Oncol. 2017; 50:708-16. https://doi.org/10.3892/ ijo.2016.3803. 
118. Sun C, Li S, Zhang F, Xi Y, Wang L, Bi Y, Li D. Long non-coding RNA NEAT1 promotes non-small cell lung cancer progression through regulation of miR-377-3pE2F3 pathway. Oncotarget. 2016; 7:51784-814. https://doi. org/10.18632/oncotarget.10108.

119. Cui Y, Zhang F, Zhu C, Geng L, Tian T, Liu H. Upregulated lncRNA SNHG1 contributes to progression of nonsmall cell lung cancer through inhibition of miR-101-3p and activation of $\mathrm{Wnt} / \beta$-catenin signaling pathway. Oncotarget. 2017; 8:17785-94. https://doi.org/10.18632/ oncotarget. 14854 .

120. Ma F, Wang SH, Cai Q, Jin LY, Zhou D, Ding J, Quan ZW. Long non-coding RNA TUG1 promotes cell proliferation and metastasis by negatively regulating miR-300 in gallbladder carcinoma. Biomed Pharmacother. 2017; 88:863-69. https://doi.org/10.1016/j.biopha.2017.01.150.

121. Wang Y, Liu Z, Yao B, Dou C, Xu M, Xue Y, Ding L, Jia Y, Zhang H, Li Q, Tu K, Jiao Y, Liu Q, et al. Long noncoding RNA TUSC7 acts a molecular sponge for miR10a and suppresses EMT in hepatocellular carcinoma. Tumour Biol. 2016; 37:11429-41. https://doi.org/10.1007/ s13277-016-4892-6.

122. Mattick JS. Challenging the dogma: the hidden layer of nonprotein-coding RNAs in complex organisms. BioEssays. 2003; 25:930-39. https://doi.org/10.1002/bies.10332.

123. Prensner JR, Iyer MK, Sahu A, Asangani IA, Cao Q, Patel L, Vergara IA, Davicioni E, Erho N, Ghadessi M, Jenkins RB, Triche TJ, Malik R, et al. The long noncoding RNA SChLAP1 promotes aggressive prostate cancer and antagonizes the SWI/SNF complex. Nat Genet. 2013; 45:1392-98. https://doi.org/10.1038/ng.2771.

124. Pandey RR, Mondal T, Mohammad F, Enroth S, Redrup L, Komorowski J, Nagano T, Mancini-Dinardo D, Kanduri C. Kcnq1ot1 antisense noncoding RNA mediates lineagespecific transcriptional silencing through chromatinlevel regulation. Mol Cell. 2008; 32:232-46. https://doi. org/10.1016/j.molcel.2008.08.022.

125. Kotake Y, Nakagawa T, Kitagawa K, Suzuki S, Liu N, Kitagawa M, Xiong Y. Long non-coding RNA ANRIL is required for the PRC2 recruitment to and silencing of p15(INK4B) tumor suppressor gene. Oncogene. 2011; 30:1956-62. https://doi.org/10.1038/onc.2010.568.

126. Yap KL, Li S, Muñoz-Cabello AM, Raguz S, Zeng L, Mujtaba S, Gil J, Walsh MJ, Zhou MM. Molecular interplay of the noncoding RNA ANRIL and methylated histone $\mathrm{H} 3$ lysine 27 by polycomb CBX7 in transcriptional silencing of INK4a. Mol Cell. 2010; 38:662-74. https://doi. org/10.1016/j.molcel.2010.03.021.

127. Tsai MC, Manor O, Wan Y, Mosammaparast N, Wang JK, Lan F, Shi Y, Segal E, Chang HY. Long noncoding RNA as modular scaffold of histone modification complexes. Science. 2010; 329:689-93. https://doi.org/10.1126/ science. 1192002.

128. Ruthenburg AJ, Wang W, Graybosch DM, Li H, Allis $\mathrm{CD}$, Patel DJ, Verdine GL. Histone $\mathrm{H} 3$ recognition and presentation by the WDR5 module of the MLL1 complex. Nat Struct Mol Biol. 2006; 13:704-12. https://doi. org/10.1038/nsmb1119.

129. Margueron R, Reinberg D. The Polycomb complex PRC2 and its mark in life. Nature. 2011; 469:343-49. https://doi. org/10.1038/nature09784.

130. Gupta RA, Shah N, Wang KC, Kim J, Horlings HM, Wong DJ, Tsai MC, Hung T, Argani P, Rinn JL, Wang Y, Brzoska P, Kong B, et al. Long non-coding RNA HOTAIR reprograms chromatin state to promote cancer metastasis. Nature. 2010; 464:1071-76. https://doi.org/10.1038/ nature 08975.

131. Liu YW, Sun M, Xia R, Zhang EB, Liu XH, Zhang ZH, Xu TP, De W, Liu BR, Wang ZX. LincHOTAIR epigenetically silences miR34a by binding to PRC2 to promote the epithelial-to-mesenchymal transition in human gastric cancer. Cell Death Dis. 2015; 6:e1802. https://doi. org/10.1038/cddis.2015.150.

132. Lee NK, Lee JH, Kim WK, Yun S, Youn YH, Park CH, Choi YY, Kim H, Lee SK. Promoter methylation of PCDH10 by HOTAIR regulates the progression of gastrointestinal stromal tumors. Oncotarget. 2016; 7:75307-18. https://doi. org/10.18632/oncotarget.12171.

133. Wu Y, Zhang L, Zhang L, Wang Y, Li H, Ren X, Wei F, Yu W, Liu T, Wang X, Zhou X, Yu J, Hao X. Long noncoding RNA HOTAIR promotes tumor cell invasion and metastasis by recruiting EZH2 and repressing E-cadherin in oral squamous cell carcinoma. Int J Oncol. 2015; 46:258694. https://doi.org/10.3892/ijo.2015.2976.

134. Sun M, Nie F, Wang Y, Zhang Z, Hou J, He D, Xie M, Xu L, De W, Wang Z, Wang J. LncRNA HOXA11-AS promotes proliferation and invasion of gastric cancer by scaffolding the chromatin modification factors PRC2, LSD1, and DNMT1. Cancer Res. 2016; 76:6299-310. https://doi. org/10.1158/0008-5472.CAN-16-0356.

135. Sui CJ, Zhou YM, Shen WF, Dai BH, Lu JJ, Zhang MF, Yang JM. Long noncoding RNA GIHCG promotes hepatocellular carcinoma progression through epigenetically regulating miR-200b/a/429. J Mol Med (Berl). 2016; 94:1281-96. https://doi.org/10.1007/ s00109-016-1442-z.

136. Li W, Sun M, Zang C, Ma P, He J, Zhang M, Huang Z, Ding Y, Shu Y. Upregulated long non-coding RNA AGAP2-AS1 represses LATS2 and KLF2 expression through interacting with EZH2 and LSD1 in non-small-cell lung cancer cells. Cell Death Dis. 2016; 7:e2225. https://doi.org/10.1038/ cddis.2016.126.

137. Reisman D, Glaros S, Thompson EA. The SWI/SNF complex and cancer. Oncogene. 2009; 28:1653-68. https:// doi.org/10.1038/onc.2009.4.

138. Milne TA, Briggs SD, Brock HW, Martin ME, Gibbs D, Allis CD, Hess JL. MLL targets SET domain methyltransferase activity to Hox gene promoters. Mol Cell. 2002; 10:1107-17. https://doi.org/10.1016/ S1097-2765(02)00741-4. 
139. Nombela C, Nombela NA, Ochoa S, Safer B, Anderson WF, Merrick WC. Polypeptide chain initiation in eukaryotes: mechanism of formation of initiation complex. Proc Natl Acad Sci USA. 1976; 73:298-301. https://doi.org/10.1073/ pnas.73.2.298.

140. Dutta R, Tiu B, Sakamoto KM. CBP/p300 acetyltransferase activity in hematologic malignancies. Mol Genet Metab. 2016; 119:37-43. https://doi.org/10.1016/j. ymgme.2016.06.013.

141. Sun XJ, Man N, Tan Y, Nimer SD, Wang L. The role of histone acetyltransferases in normal and malignant hematopoiesis. Front Oncol. 2015; 5:108. https://doi. org/10.3389/fonc.2015.00108.

142. Liu C, Lin J. Long noncoding RNA ZEB1-AS1 acts as an oncogene in osteosarcoma by epigenetically activating ZEB1. Am J Transl Res. 2016; 8:4095-105.

143. Schmidt K, Joyce CE, Buquicchio F, Brown A, Ritz J, Distel RJ, Yoon CH, Novina CD. The lncRNA SLNCR1 mediates melanoma invasion through a conserved SRA1like region. Cell Reports. 2016; 15:2025-37. https://doi. org/10.1016/j.celrep.2016.04.018.

144. Xing Z, Lin A, Li C, Liang K, Wang S, Liu Y, Park PK, Qin L, Wei Y, Hawke DH, Hung MC, Lin C, Yang L. IncRNA directs cooperative epigenetic regulation downstream of chemokine signals. Cell. 2014; 159:1110-25. https://doi. org/10.1016/j.cell.2014.10.013.

145. Ji Q, Zhang L, Liu X, Zhou L, Wang W, Han Z, Sui H, Tang Y, Wang Y, Liu N, Ren J, Hou F, Li Q. Long non-coding RNA MALAT1 promotes tumour growth and metastasis in colorectal cancer through binding to SFPQ and releasing oncogene PTBP2 from SFPQ/PTBP2 complex. Br J Cancer. 2014; 111:736-48. https://doi.org/10.1038/bjc.2014.383.

146. Glickman MH, Ciechanover A. The ubiquitin-proteasome proteolytic pathway: destruction for the sake of construction. Physiol Rev. 2002; 82:373-428. https://doi. org/10.1152/physrev.00027.2001.

147. Kretz M, Siprashvili Z, Chu C, Webster DE, Zehnder A, Qu K, Lee CS, Flockhart RJ, Groff AF, Chow J, Johnston D, Kim GE, Spitale RC, et al. Control of somatic tissue differentiation by the long non-coding RNA TINCR. Nature. 2013; 493:231-35. https://doi.org/10.1038/nature11661.

148. Maetzel D, Denzel S, Mack B, Canis M, Went P, Benk M, Kieu C, Papior P, Baeuerle PA, Munz M, Gires O. Nuclear signalling by tumour-associated antigen EpCAM. Nat Cell Biol. 2009; 11:162-71. https://doi.org/10.1038/ncb1824.

149. Yang F, Huo XS, Yuan SX, Zhang L, Zhou WP, Wang F, Sun $\mathrm{SH}$. Repression of the long noncoding RNA-LET by histone deacetylase 3 contributes to hypoxia-mediated metastasis. Mol Cell. 2013; 49:1083-96. https://doi.org/10.1016/j. molcel.2013.01.010.

150. Kuwano Y, Pullmann R Jr, Marasa BS, Abdelmohsen K, Lee EK, Yang X, Martindale JL, Zhan M, Gorospe M. NF90 selectively represses the translation of target mRNAs bearing an AU-rich signature motif. Nucleic Acids Res. 2010; 38:225-38. https://doi.org/10.1093/nar/gkp861.

151. Sánchez-Tilló E, Lázaro A, Torrent R, Cuatrecasas M, Vaquero EC, Castells A, Engel P, Postigo A. ZEB1 represses E-cadherin and induces an EMT by recruiting the SWI/SNF chromatin-remodeling protein BRG1. Oncogene. 2010; 29:3490-500. https://doi.org/10.1038/onc.2010.102.

152. Postigo AA, Dean DC. ZEB represses transcription through interaction with the corepressor CtBP. Proc Natl Acad Sci USA. 1999; 96:6683-88. https://doi.org/10.1073/ pnas.96.12.6683.

153. Wang TH, Lin YS, Chen Y, Yeh CT, Huang YL, Hsieh TH, Shieh TM, Hsueh C, Chen TC. Long non-coding RNA AOC4P suppresses hepatocellular carcinoma metastasis by enhancing vimentin degradation and inhibiting epithelialmesenchymal transition. Oncotarget. 2015; 6:23342-57. https://doi.org/10.18632/oncotarget.4344.

154. Ruland J. Return to homeostasis: downregulation of NF-кB responses. Nat Immunol. 2011; 12:709-14. https://doi. org/10.1038/ni.2055.

155. Chaturvedi MM, Sung B, Yadav VR, Kannappan R, Aggarwal BB. NF- $\kappa \mathrm{B}$ addiction and its role in cancer: 'one size does not fit all'. Oncogene. 2011; 30:1615-30. https:// doi.org/10.1038/onc.2010.566.

156. Fornier MN, Rathkopf D, Shah M, Patil S, O'Reilly E, Tse AN, Hudis C, Lefkowitz R, Kelsen DP, Schwartz GK. Phase I dose-finding study of weekly docetaxel followed by flavopiridol for patients with advanced solid tumors. Clin Cancer Res. 2007; 13:5841-46. https://doi. org/10.1158/1078-0432.CCR-07-1218.

157. Liu B, Sun L, Liu Q, Gong C, Yao Y, Lv X, Lin L, Yao H, Su F, Li D, Zeng M, Song E. A cytoplasmic NF-кB interacting long noncoding RNA blocks I $\mathrm{B}$ phosphorylation and suppresses breast cancer metastasis. Cancer Cell. 2015; 27:370-81. https://doi.org/10.1016/j.ccell.2015.02.004.

158. Qu L, Ding J, Chen C, Wu ZJ, Liu B, Gao Y, Chen W, Liu F, Sun W, Li XF, Wang X, Wang Y, Xu ZY, et al. Exosome-transmitted lncarsr promotes sunitinib resistance in renal cancer by acting as a competing endogenous RNA. Cancer Cell. 2016; 29:653-68. https://doi.org/10.1016/j. ccell.2016.03.004.

159. Chimge NO, Baniwal SK, Little GH, Chen YB, Kahn M, Tripathy D, Borok Z, Frenkel B. Regulation of breast cancer metastasis by Runx 2 and estrogen signaling: the role of SNAI2. Breast Cancer Res. 2011; 13:R127. https://doi. org/10.1186/bcr3073.

160. Katafiasz D, Smith LM, Wahl JK 3rd. Slug (SNAI2) expression in oral SCC cells results in altered cell-cell adhesion and increased motility. Cell Adhes Migr. 2011; 5:315-22. https://doi.org/10.4161/cam.5.4.17040.

161. Wang C, Liu X, Huang H, Ma H, Cai W, Hou J, Huang L, Dai Y, Yu T, Zhou X. Deregulation of Snai2 is associated with metastasis and poor prognosis in tongue squamous 
cell carcinoma. Int J Cancer. 2012; 130:2249-58. https:// doi.org/10.1002/ijc.26226.

162. Yan J, Dang Y, Liu S, Zhang Y, Zhang G. LncRNA HOTAIR promotes cisplatin resistance in gastric cancer by targeting miR-126 to activate the PI3K/AKT/MRP1 genes. Tumour Biol. 2016; 37:16345-55. https://doi.org/10.1007/ s13277-016-5448-5.

163. Yue B, Cai D, Liu C, Fang C, Yan D. Linc00152 functions as a competing endogenous RNA to confer oxaliplatin resistance and holds prognostic values in colon cancer. Mol Ther. 2016; 24:2064-77. https://doi.org/10.1038/ mt.2016.180.

164. Li P, Zhang X, Wang H, Wang L, Liu T, Du L, Yang Y, Wang C. MALAT1 is associated with poor response to oxaliplatinbased chemotherapy in colorectal cancer patients and promotes chemoresistance through EZH2. Mol Cancer Ther. 2017; 16:739-51. https://doi.org/10.1158/1535-7163. MCT-16-0591.

165. Fang Q, Chen X, Zhi X. Long non-coding RNA (LncRNA) urothelial carcinoma associated 1 (UCA1) increases multidrug resistance of gastric cancer via downregulating miR-27b. Med Sci Monit. 2016; 22:3506-13. https://doi. org/10.12659/MSM.900688.

166. Shang C, Guo Y, Zhang J, Huang B. Silence of long noncoding RNA UCA1 inhibits malignant proliferation and chemotherapy resistance to adriamycin in gastric cancer. Cancer Chemother Pharmacol. 2016; 77:1061-67. https:// doi.org/10.1007/s00280-016-3029-3.

167. Takahashi K, Yan IK, Kogure T, Haga H, Patel T. Extracellular vesicle-mediated transfer of long noncoding RNA ROR modulates chemosensitivity in human hepatocellular cancer. FEBS Open Bio. 2014; 4:458-67. https://doi.org/10.1016/j.fob.2014.04.007.

168. Svoboda M, Slyskova J, Schneiderova M, Makovicky P, Bielik L, Levy M, Lipska L, Hemmelova B, Kala Z, Protivankova M, Vycital O, Liska V, Schwarzova L, et al. HOTAIR long non-coding RNA is a negative prognostic factor not only in primary tumors, but also in the blood of colorectal cancer patients. Carcinogenesis. 2014; 35:1510 15. https://doi.org/10.1093/carcin/bgu055.

169. Guo F, Yu F, Wang J, Li Y, Li Y, Li Z, Zhou Q. Expression of MALAT1 in the peripheral whole blood of patients with lung cancer. Biomed Rep. 2015; 3:309-12. https://doi. org/10.3892/br.2015.422.

170. Xie H, Ma H, Zhou D. Plasma HULC as a promising novel biomarker for the detection of hepatocellular carcinoma. BioMed Res Int. 2013; 2013:136106. https:// doi.org/10.1155/2013/136106.

171. Zhao Y, Guo Q, Chen J, Hu J, Wang S, Sun Y. Role of long non-coding RNA HULC in cell proliferation, apoptosis and tumor metastasis of gastric cancer: a clinical and in vitro investigation. Oncol Rep. 2014; 31:358-64. https://doi. org/10.3892/or.2013.2850.
172. Hu P, Chu J, Wu Y, Sun L, Lv X, Zhu Y, Li J, Guo Q, Gong C, Liu B, Su S. NBAT1 suppresses breast cancer metastasis by regulating DKK1 via PRC2. Oncotarget. 2015; 6:3241025. https://doi.org/10.18632/oncotarget.5609.

173. Jia J, Li F, Tang XS, Xu S, Gao Y, Shi Q, Guo W, Wang $\mathrm{X}, \mathrm{He} \mathrm{D}$, Guo P. Long noncoding RNA DANCR promotes invasion of prostate cancer through epigenetically silencing expression of TIMP2/3. Oncotarget. 2016; 7:37868-81. https://doi.org/10.18632/oncotarget.9350.

174. He W, Cai Q, Sun F, Zhong G, Wang P, Liu H, Luo J, Yu H, Huang J, Lin T. linc-UBC1 physically associates with polycomb repressive complex 2 (PRC2) and acts as a negative prognostic factor for lymph node metastasis and survival in bladder cancer. Biochim Biophys Acta. 2013; 1832:1528-37. https://doi.org/10.1016/j. bbadis.2013.05.010.

175. Sun NX, Ye C, Zhao Q, Zhang Q, Xu C, Wang SB, Jin ZJ, Sun SH, Wang F, Li W. Long noncoding RNA-EBIC promotes tumor cell invasion by binding to EZH2 and repressing E-cadherin in cervical cancer. PLoS One. 2014; 9:e100340. https://doi.org/10.1371/journal.pone.0100340.

176. Li J, Gao J, Tian W, Li Y, Zhang J. Long non-coding RNA MALAT1 drives gastric cancer progression by regulating HMGB2 modulating the miR-1297. Cancer Cell Int. 2017; 17:44. https://doi.org/10.1186/s12935-017-0408-8.

177. Qi Y, Ooi HS, Wu J, Chen J, Zhang X, Tan S, Yu Q, Li YY, Kang Y, Li H, Xiong Z, Zhu T, Liu B, et al. MALAT1 long ncRNA promotes gastric cancer metastasis by suppressing PCDH10. Oncotarget. 2016; 7:12693-703. https://doi. org/10.18632/oncotarget.7281.

178. Li Z, Hou P, Fan D, Dong M, Ma M, Li H, Yao R, Li Y, Wang G, Geng P, Mihretab A, Liu D, Zhang Y, et al. The degradation of EZH2 mediated by lncRNA ANCR attenuated the invasion and metastasis of breast cancer. Cell Death Differ. 2017; 24:59-71. https://doi.org/10.1038/ cdd.2016.95 PMID:27716745.

179. Wang YJ, Liu JZ, Lv P, Dang Y, Gao JY, Wang Y. Long noncoding RNA CCAT2 promotes gastric cancer proliferation and invasion by regulating the E-cadherin and LATS2. Am J Cancer Res. 2016; 6:2651-60.

180. Wu Y, Liu H, Shi X, Yao Y, Yang W, Song Y. The long non-coding RNA HNF1A-AS1 regulates proliferation and metastasis in lung adenocarcinoma. Oncotarget. 2015; 6:9160-72. https://doi.org/10.18632/oncotarget.3247.

181. Yang XJ, Huang CQ, Peng CW, Hou JX, Liu JY. Long noncoding RNA HULC promotes colorectal carcinoma progression through epigenetically repressing NKD2 expression. Gene. 2016; 592:172-78. https://doi. org/10.1016/j.gene.2016.08.002. 